\title{
Szent-Györgyi Albert - a sokoldalú biológus
}

\section{Albert Szent-Györgyi - the versatile biologist}

Varga János mérnöktanár

vargaj.szfv@gmail.com

Initially submitted March 30, 2020; accepted for publication Apr.28, 2020

\begin{abstract}
Albert Szent-Györgyi (born September 16, 1893, in Budapest) is the only Hungarian citizen scientist who earned the Nobel Prize while living and working in his home country. Szent-Györgyi's name is connected to the research related to ascorbic acid or Vitamin C. However, his scientific work was much more diverse, he could have received even five Nobel Prizes.

What were his scientific achievements? Why did many think that he should receive the Nobel Peace Prize? Who got the Nobel Peace Prize instead of him? What is his family background? Why did he change the spelling of his name? Was he really a spy during the World War II? What was his disagreement with Edward Teller about? What are the similarities between Albert Einstein and him? Why was he asked to write Einstein's obituary and what did he write about him? What was his relationship with John von Neumann? What has happened to his third wife, Susan Wichterman? Was he a secret poet? Where is the Szent-Györgyi Collection located outside Szeged and what does it contain? Why is his memorial plaque in a granary building at Kiskérpuszta, Hungary? Where is he buried? What are the misconceptions about him?
\end{abstract}

Kulcsszavak: antioxidánsok, C-vitamin, citrátciklus, izommüködés biokémiája, Einstein, kém, szabad gyökök, rákkutatás

Keywords: antioxidants, vitamin C, citrate cycle, biochemistry of muscle function, Einstein, spy, free radicals, cancer research

A polihisztor kifejezés alapvetően olyan tudóst jelöl, aki többféle tudományágat kutat és önmaga is kiemelkedő új felfedezésekkel, felismerésekkel gazdagítja az emberiség tudományos ismereteit. Tudományos értelemben úttörő polihisztorok föleg az ókorban, az iszlám aranykorában és a reneszánsz idején éltek és alkottak -mint pl. Leonardo-, de a XX. század elején eltünedeztek, mert a század második felére a tudományok olyannyira szerteágazó, összetett ismeretanyaggá bővültek, hogy az új eredmények eléréséhez muszáj volt résztudományokat alkotni és egyre inkább specializált kutatásokat folytatni. Egyegy tudományos diszciplína olyan óriásira duzzadt, hogy annak áttekintésére egy tudós ma már nem vállalkozhat. A fizikát illetően például a Nobel-díjas Wigner Jenő jelentette ki, hogy legalább száz tudós szükséges a teljes áttekintésére, és ő maga -akit egyébként az egyik legsokoldalúbb kutatónak tartottak- a szakcikkek felét nem is érti. Manapság is vannak sokoldalú ismeretekkel rendelkező kutatók, akiket hagyományos értelemben ugyan nem nevezhetünk polihisztornak, de saját szakmájukban több szakterületen is kiemelkedő eredményeket értek el. Ezek egyike Szent-Györgyi Albert. Ez a tanulmány kísérlet arra, hogy bemutassa gazdag életmüvet, de természetesen még jelentős terjedelme ellenére sem

http://www.kaleidoscopehistory.hu

Varga János mérnöktanár 
Kaleidoscope

törekedhet teljességre, és pláne nem vállalkozhat arra, hogy tevékenységének egyéb, nem tudományos diplomáciai, politikai, közéleti stb.- oldalát is részletesen bemutassa.

Szent-Györgyi Albert apai családja - mindkét ágon - erdélyi kisnemesi, székelyföldi eredetü. A Szentgyörgyi család 'Nagyrápólti' előneve egy alig félszáz lelket számláló katolikus falucska neve. A családi legenda szerint a Szentgyörgyi (így egybeírva!) család régebben adományozott nemesi oklevelét 1836-ban V. Ferdinánd megerősítette. A Szentgyörgyiek Szentgyörgyi Sámuel kalotaszegi református prédikátorig tudják visszavezetni a családfájukat, aki 1608-ban kapott nemességet Báthory Gábor erdélyi fejedelemtől. Szentgyörgyi alakban szerepel a neve a budapesti Kálvin téri református parókia keresztelési anyakönyvében (1893. november 5-ei bejegyzés) és orvosi végbizonyítványában (1917) is. Korai publikációit is Szentgyörgyiként jegyzi. 1937-ben a belügyminisztérium útján állapíttatta meg a névírás helyes alakját. Nem nevének megváltoztatását kérte tehát a belügyminisztériumtól (ez is egy tévhit!), hanem a sok névváltozat közül a helyes alak megállapítását. A névírás történetét maga a tudós meséli el a Pesti Hírlap, 1937. november 5-i számának 4. oldalán. A Hogyan írja a nevét a Nobel-díjas tudós c. cikk felkutatása a Szegedi Somogyi Könyvtár Vasváry-gyüjteménye vezetőjének Kórász Máriának köszönhetö ${ }^{1}$.

\section{Hogyan irja a nevét a Nobel-dijas tudós}

Szeged, nov. 4. (A Pesti Hirlap szegedi tudósitójától.) Érdemes lenne megállapitani, hogy az elmult héten a világsajtó hányszor közölte dr. Szent-Györgyi Albert nevét. De barmennyire vilaghirüvé tette is a magyar tudós nevét a stockholmi dóntés, ez a név rengeteg vâltozatban jelent meg a lapok hasábjain. , szent györgyi"-nek, "Szentgyörgyi"-nek, "Szentgyörgyi-"nek, "Szent-Györgyi"-nek irták a iapok. Senki sem tudta biztosan, hogy maga a tudós hogyan íja. A Pesti Hirlap szegedi munkatársa - hogy tisztázza a kérdést - a Nobel-dijas tudóshoz fordult felvilàgositásért. - Sokáig magam sem voltam biztos abban, hogyan is irjam családi nevemet - hangzott a válasz. Veglgpróbáltam minden változatot, régi esaládi okmányolcat tanulmányoztam át, hogy felkutassam az iguzságot, de ezekbōl az okmányokból is az derült ki, hogy a multban sem irta a csalad egyöntetủen' a ne-

vèt. A családi iratokban is minden változatban elōfordul a név. Végül is a belígyministérium utján állapittattam meg a névirás helyes alakját. Ebben a pillanatban tehât a belügyminisztérium megállapitása szerint igy kell helyesen irni: Szent-Gyürgyl. Most már ên is igy irom.

Es a professzor rögtön autogramot is adott a

Pesti Hirlap számára. Ime az aláirása:

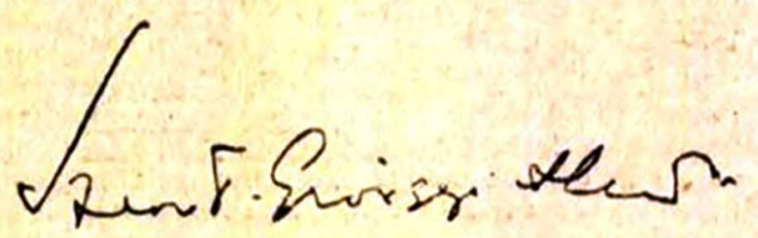

1. ábra Szent-Györgyi neve írásai

Anyai dédapja Lenhossék Mihály orvos, egyetemi tanár, Széchenyi István háziorvosa és barátja volt. Anyai nagyanyja Bossányi Emma (1843-1918) az Ungvárról származó Bossányi Henrik zsidó származású orvos lánya volt. [14, 23. o.]

\section{Főbb kutatási területei}

\section{Sejtlégzés-Hexuronsav-aszkorbinsav-C-vitamin}

Szent-Györgyit a C-vitamin feltalálójaként könyvelte el a média, és emiatt a közvélemény is, pedig ez egy tévhit, ugyanis a közhiedelemmel ellentétben nem ő, hanem AXEL HoLst (1860-1931) és THEODOR FRÖHLICH (1870-1947) norvég kutatók fedezték fel a C-vitamint 1907-ben, akik elkülönítették ezt a létfontosságú anyagot, de a használható mennyiség előállíthatóságának megoldása nélkül.

http://www.kaleidoscopehistory.hu

Varga János mérnöktanár 


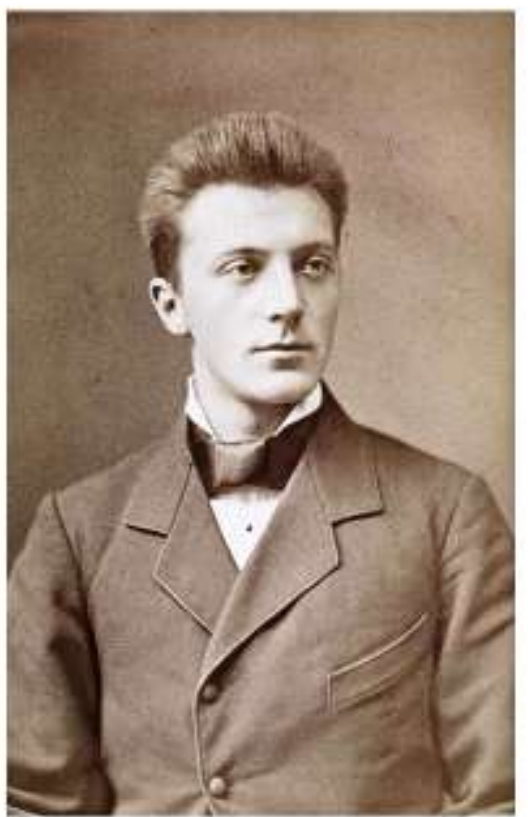

Axel Holst (1860-1931) norvég higiéniai bakteriológiai professzor

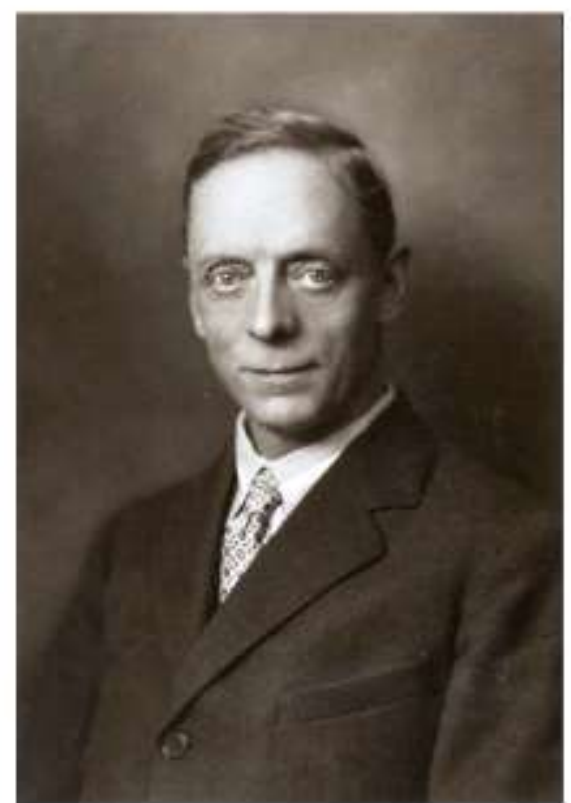

Theodor Frölich (1870-1947) norvég orvos, és gyermekgyógyász professzor

2. ábra A C-vitamin feltalálói Alex Holst és Theodor Frölich

Szent-Györgyit a sejtes légzés és az energiatermelés érdekelte, és ebben az időben megvizsgálta a "barnulás" folyamatát a növényeknél - ahol egyes növények hervadáskor elbarnulnak. Felfedezte, hogy a barnulás akkor következik be, amikor a sejt szinten károsodott mechanizmusok nem tudnak elég hidrogént biztosítani az oxidáció megelőzésére, ami a barnulást okozza. Aztán azok a növények keltették fel érdeklődését, amelyek nem barnultak. Miközben egy sor kísérletet végzett a citrus növényekkel, úgy találta, hogy peroxidázzal oxidáló hatású növényi enzimet okozhat, és késlelteti a barnulást a citruslevet tartalmazó peroxidáz hozzáadásával. Citruslevekben elkülönítette a barnulás ellensúlyozásáért felelös közeget (agent), "hexuronsavnak" nevezte, és 1928-ban megjelentette megállapításait. Szent-Györgyi tehát már 1928-ban bizonyos emberi és növényi szövetekben elkülönítette (izolálta) és hexuronsavként ${ }^{2}$ azonosította (identifikálta) a később C-vitaminnak nevezett anyagot. Rájött, hogy ez az anyag a narancsban, a káposztában és a füszerpaprikában is megtalálható, biológiai hatásait tanulmányozta. Tisztázta annak a sejt életfolyamataiban való szerepét, valószínüsítette kémiai felépítését. Sőt -egy újabb meglepetés- nem elsősorban a C-vitaminért kapta 1937-ben az orvosi és élettani Nobel-díjat, hanem a „,biológiai égés (oxidációs) folyamatok kutatása terén elért felfedezéséért, különös tekintettel a $C$ vitaminra és a fumársav katalizisére ${ }^{3}$."

Több mint egy évtizedes külföldi tartózkodásából hívta haza 1928-ban KLEBELSBERG KuNÓ kultuszminiszter a szegedi egyetem újjá szerveződő orvosi kémiai tanszékére. Szegeden 1931 januárjától kezdte meg kutatói és tanári tevékenységét az orvosi vegytani intézet professzoraként.

http://www.kaleidoscopehistory.hu

Varga János mérnöktanár 


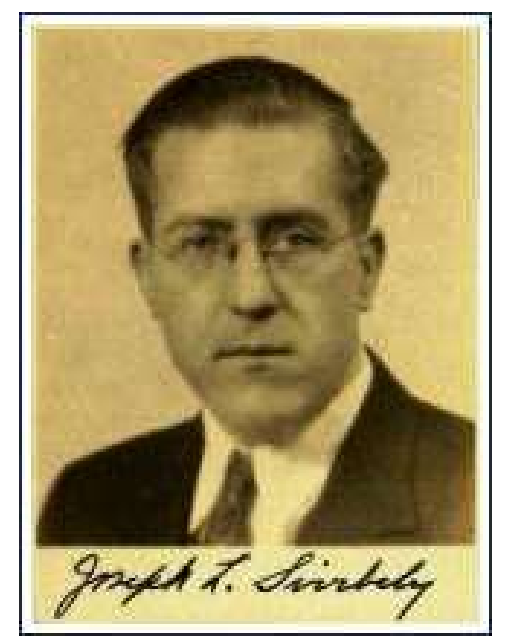

3. ábra Joseph Louis Svirbely (1904-1996), magyar származású amerikai vegyész

1931 szeptemberében egy magyar származású amerikai vendégkutató JOSEPH L. SVIRBELY érkezett Szent-Györgyi Alberthez. Apja vasmunkásként vándorolt ki az Egyesült Államokba. Azzal a szándékkal jött Szegedre, hogy biokémiai tanulmányokat folytasson. Szent-Györgyi Albert és Svirbely tengerimalacokon végzett kísérletekkel bizonyították be, hogy az állati mellékvesekéregben talált anyag, a hexuronsav azonos a C-vitaminnal, amelyet addig kémiailag nem ismertek, csak skorbutellenes hatásáról tudtak. Svirbely Pittsburghben munkatársa volt CHARLES GLEN KING (1896-1988) amerikai professzornak. King is vitaminkutatással foglalkozott, a C-vitamin azonosításán is dolgozott. Svirbely 1932 márciusában beszámolt volt professzorának a Szegeden végzett kutatásairól. King ezt követően 1932. április 1-én, annak ellenére, hogy ilyen anyag nem is állt a rendelkezésére- a Science címü folyóiratban rövid híradást tett közzé, mely szerint kutatási eredményeik alapján a C-vitamin azonos a hexuronsavval. Szent-Györgyi és Svirbely közös tanulmánya a Nature címü tudományos folyóirat 1932. április 16-i számában jelent meg, amelyben beszámoltak felfedezésükröl. A felfedezés körül így elsőségi vita alakult ki. Azonban kiderült, hogy Szent-Györgyi Albert már 1932. március 18-án, a Budapesti Kir. Orvosegyesület ülésén tartott előadásában bejelentette, hogy a hexuronsav és a C-vitamin ugyanaz az anyag: „Nyilvánosság előtt először ezúttal mondjuk ki, hogy a hexuronsav (aszkorbinsav) és a C-vitamin azonosak.” 1932. március 26-án az Orvosi Hetilap is beszámolt az előadáson elhangzottakról, azaz arról, hogy a hexuronsav nem más, mint a C-vitamin. Az egyesült államokbeli tudományos közvélemény tehát hibásan tekinti Kinget a C-vitamin azonosítójának. A hexuronsavat ezután Norman Haworth professzorral közösen nevezték el aszkorbinsavnak.

\section{A Nobel-díj}

Az orvosi/fiziológiai díjat -amely egy diplomából, egy aranyéremből és 40.000 \$ készpénzből áll1937-ben kapta. A dijjra két másik jelölt is volt: birminghami kollégája, Norman Haworth, és a vitaminok egy másik úttörője Paul Karrer. A Karolinska Intézet tanácskozásain hosszú, parázs vita folyt, amely annyira elmérgesedett, hogy amikor a bizottság elnöke, Hans Christian Jacobeus kijött, hogy bejelentse a döntést, ott helyben szívrohamot kapott, összeesett és meghalt. A bizottság úgy határozott, hogy SzentGyörgyi egyedül (nem megosztva) kapja meg a díjat. [27, 118] 
Kaleidoscope

Nem sokkal később viszont azt is bejelentette a Nobel Bizottság, hogy „Az 1937-es kémiai Nobeldíjat Walton Norman Haworth angol kémikus, a »szénhidrátok és C-vitamin kémiai szerkezetének vizsgálataiért» és Paul Karrer svájci kémikus »a karotinoidokra, flavinokra valamint az A és B2 vitaminokra vonatkozó vizsgálataiért« kapja egyenlö arányban megosztva. [15]” A szénhidrátok, fehérjék és zsírok mellett testünknek vízre, sókra és vitaminok néven ismert anyagokra is szüksége van a megfelelő növekedésre és müködésre. Norman Haworth tanulmányozta a szénhidrátok összetételét, és 1928 körül megfogalmazta a cukor, keményítő és cellulóz különböző formáinak összetételét és szerkezetét. 1933-ban Haworth meghatározta a C-vitamin molekuláris szerkezetét - olyan anyagot, amely szükséges ahhoz, hogy elkerüljük a skorbutos megbetegedést. Többek között ezek az eredmények tették lehetővé a C-vitamin mesterséges előállítását. Az a Haworth, akit Szent-Györgyi látott el C-vitaminnal, és aki így neki köszönhetően tudta kémiailag azonosítani a C-vitamint, amit a skorbutot megelőző hatására utalva együtt neveztek el aszkorbinsavnak. 1931-ben Paul Karrer-nek sikerült kivonni az A-vitamint a tökehal-olajból és meghatározni összetételét. Az A-vitamin szükséges ahhoz, hogy a test növekedjen, és egyik összetevője a karotin, amelyet sárgarépában és másutt találunk. Ez volt az első olyan vitamin, amelynek szerkezetét feltérképezte. 1933-ban Karrer meghatározta a B2-vitamin szerkezetét is, ami lehetővé tette a vitamin termelését mesterséges eszközökkel.

Részlet a Nobel-díj átvételekor 1937. december 11-én mondott Oxidation, Energy Transfer, and Vitamins (Oxidáció, energiaátvitel és vitaminok) című előadásából: [24, 446. o.]

„I succeeded in isolating the substance in question from adrenals and various plants, and in showing that it corresponded to the formula C6H8O6 and was related to the carbohydrates. [...] Then the Mayo Foundation and Prof. Kendall came to my help on a large scale, and made it possible for me to work, regardless of expense, on the material from large American slaughter-houses. [...] From the beginning I had suspected that the substance was identical with vitamin C. ,,"

„Eredményesen izolálhattam ezt az érzékeny anyagot mind a mellékveséböl, mind a különféle növényekböl, és megállapítottam, hogy képlete $\mathrm{C}_{6} \mathrm{H}_{8} \mathrm{O}_{6}$, és a szénhidrátokhoz tartozik. [...] Ekkor a Mayo alapítvány és maga Kendall professzor nagylelküen segítségemre sietett meghívásával; az amerikai vágóhidak azután bőségesen bocsátottak rendelkezésemre mellékvesét. [...] Kezdettől fogva gyanítottam, hogy a hexuronsav azonos a Cvitaminnal." - a szerző fordítása.

Az, hogy nem ö a C vitamin feltalálója a szó legszorosabb értelmében, semmit sem von le eredményének jelentőségéből, hiszen gyakorlatilag a $\mathrm{C}$-vitamin nagy mennyiségü elöállítása és a felhasználhatósága mindenképpen az ő nevéhez füződik.

\section{A C-vitamin mesterséges előállítása}

A The New York Times hasábjain az 1933. április 2-i számban megjelent márc. 17-i budapesti tudósítás arról ad hírt, hogy „Általános tudományos érdeklődést keltett a kiváló magyar kémikusnak, dr. Szent-Györgyi Albertnek, a szegedi egyetem professzorának az a bejelentése, hogy 10 éves kutatómunka után fölfedezte a $C$-vitamin mesterséges elöállitásának módszerét. Szent-Györgyi professzor azt állítja, hogy kimutatta: a vitamin nagy mennyiségben van jelen a magyar paprikában ${ }^{4}$ vagy édes borsban, amely legalább négyszer annyi C-vitamint tartalmaz, mint a narancs vagy a citrom. ... kinyerte a $\mathrm{C}$-vitamint, amit por vagy tabletta formájában akár csecsemőnek is beadhatnak. Szent-Györgyi Albert kutatómunkáját http://www.kaleidoscopehistory.hu

Varga János mérnöktanár 
anyagilag egy tehetős amerikai barát támogatta. A professzort már Berlinbe, Stockholmba és Koppenhágába is meghívták, hogy fölfedezéséröl előadásokat tartson. [22, 6. o.]" Ez egy újabb, a tömeggyártás megvalósításával kapcsolatos tudományos eredmény. Magyarország ezáltal abszolút monopolhelyzetbe került, amiből további tudományos elönyt, és gazdasági hasznot lehetett volna kovácsolni, de Szent-Györgyi a gyors tudományos eredmények elérése miatt inkább vizsgálható mennyiségü mintákat küldött szét számos külföldi laboratóriumnak, így szinte akaratlanul is megteremtette saját konkurenciáját, és a szabadalmakkal sem foglalkozott. Sokan úgy vélik, hogy Szeged ezzel elszalasztott egy újabb Nobel-díjat, mivel a C-vitamin szerkezeti kutatását még ha kicsit később is, de Szegeden is el lehetett volna végezni, másrészt pedig hazánknak kellett volna elárasztani a világot ezzel az értékes, nagy hasznot hozó anyaggal. Igaz ma is gyártanak Magyarországon C-vitamint, de a piaci részesedés, így a haszon nagy része is Kínáé.

\section{A citrátciklus főbb lépéseinek azonosítása}

1934-36 között Szegeden folytatta a szöveti biológiai oxidáció kutatását. Azokat a szerves vegyületeket kezdte el tanulmányozni, amelyekről tudott volt, hogy szerepet játszanak a szénhidrátok lebontási termékeinek átalakításában szén-dioxiddá, vízzé, és egyéb olyan anyagokká, melyek szükségesek a sejt számára felhasználható energia előállításához. A kétbázisú szerves savak katalitikus funkcióját igazolta a szövetlégzésben. Munkája megteremtette az alapokat SIR HANS KREBS vizsgálatai számára, aki két évvel később 1937-ben a teljes átalakítási ciklus összes lépését meghatározta, így méltán nevezik az életnek ezt a kulcsfontosságú jelenségét Szent-Györgyi-Krebs citrátciklusnak/körfolyamatnak. A Nobel-díjasok hivatalos honlapja így összegzi Krebs munkásságát: „A tápanyagok a sejtjeinkben lebomlanak, és energiát adnak a sejtek építéséhez. Miután Szent-Györgyi Albert számos fontos reakciót azonosított ezen anyagcsere folyamatokban, 1937-ben Hans Krebs képes volt teljes képet készíteni az anyagcsere fontos részéről - a citromsav ciklusról. Ebben a folyamatban, amely ciklikus, és több lépésből áll, a tápanyagok átalakulnak más molekulákká, nagy mennyiségü kémiai energiával. Az utóbbiakat végül adenozintrifoszfáttá (ATP) alakítják át, amely kémiai energiát biztosít a biokémiai folyamatok megkönnyítésére a sejtben. [18]" A német zsidó származású Krebs már, mint brit biokémikus a szintén zsidó származású FRITZ LIPMANN német-amerikai biokémikussal megosztva nyerte el az orvosi-élettani Nobel-díjat 1953ban. Angliai elhelyezkedéséhez Szent-Györgyitől kapott fontos támogatást.

„1937-ben Hans Krebs teljes képet adott az anyagcsere fontos részéről - a citromsav ciklusról. Ebben a folyamatban, amelynek több lépése van, a tápanyagok más molekulákká alakulnak át, nagy mennyiségü kémiai energiával. A folyamat egy fontos része még mindig hiányzott - egy olyan anyag, amely egy fehérjével együtt olyan enzimet alkot, amely megkönnyíti a fontos lépést. 1946-ban az anyagot FRITZ LIPMANN fedezte fel, aki leírta szerepét, és a coenzim A nevet adta neki. [19]” Egy hármójuk között 1/3 arányban megosztott Nobel-díj sokak szerint igazságos döntés lett volna.

\section{Izomkutatás}

1945 és 1947 között a budapesti tudományegyetem orvosi karának biokémia-professzora volt, és az izommüködés biokémiájának szentelte kutatásait. Egyenrangú tudósként egyetlen női munkatársát, Banga Ilonát (Iluskát) (1906-1998) fogadta el, aki egy új fehérjét fedezett fel az izomban, melyet aktinnak 
Kaleidoscope

nevezett el, aminek izolálását Straub F. Brunó (1914-1996) végezte. Kimutatta, hogy - egy másik izomfehérjével, a miozinnal társítva (un. aktomiozin szálat alkotva) - ez a fehérje felelős az izom összehúzódásáért, továbbá, hogy az összehúzódáshoz szükséges energia közvetlen forrása az adenozintrifoszfát (ATP) nevü vegyület. A test izmai vékony rostok, amelyeket vékonyabb rostok, rost szálacskák alkotnak, amelyek végül még finomabb szálakból állnak össze. Az izmok azért húzódnak össze, mert a legvékonyabb szálak összehúzódnak. Az aktomiozin szál nem mozog, csak akkor húzódik össze, ha ATPt vesz föl. „Ami az izom-összehúzódást előidézi nem kémiai reakció, hanem elektronfolyamat. [22, 33. o.]" Kémcsőben reprodukálni tudta az izom életfunkcióját, és lehetővé tette analízisét. Ezirányú kutatásait, mint a Massachusett-i Woods Hole Izomkutató Intézet ${ }^{5}$ igazgatója irányította, jelentős támogatást kapva az Amerikai Izomsorvadáselleni Társaságtól. Szorgalmazta a kémia és az atomfizika házasitását, remélve, hogy így az alapkutatásnak olyan irányzata alakulna ki, amelyik az élő anyag legbensőbb folyamatainak részleteivel foglalkozik. Szakmabeliek az e téren elért eredményeit többre értékelik, mint a C-vitaminhoz kapcsolódó kutatását, ezért úgy gondolják, hogy ha esetleg 1937-ben nem kapott volna Nobel-díjat, az izomkutatás területén elért eredményei meghozták volna számára a legmagasabb tudományos elismerést! S hogy ezt megérdemelte volna, jól bizonyítja, hogy 1952. május 18-i cikkében még a The New York Times is úgy mutatja be, mint ,aki izomkutatásaiért kapott Nobel-díjat [22, 21. o.].”

\section{Szabad gyökök - antioxidánsok felismerése}

Szakmabeliek szerint a legnagyobb tudományos eredménye a szabad gyökök biológiai hatásának megsejtése, orvoslásuknak, a gyökfogóknak (antioxidánsoknak) a felismerése volt. Az élölények legföbb energiaforrása az oxigén, melynek hasznosításakor azonban un. labilis oxigénszármazékok, más néven szabad gyökök keletkeznek, melyeknek az a jellemzöjük, hogy a 8 elektronjukból egy hiányzik. Ezek a környezetükben lévő molekulákat megtámadják, hogy tőlük elektront szerezzenek. A környezeti ártalmak, dohányzás, levegőszennyezés, a táplálékok ártó összetevői, a sugárzások, bizonyos gyógyszerek hatására szervezetünkben nagy mennyiségü szabad gyökök keletkezik, melyeknek fontos szerepe van a rák, az infarktus, az érelmeszesedés, bizonyos idegrendszeri betegségek, az öregedés, ezen belül az időskori szürkehályog létrejöttében. Az első igazolt gyökfogó éppen a C-vitamin volt. Ezért is kaphatott volna egy Nobel-díjat. Szent-Györgyinek tehát 4 Nobel-díjas ötlete volt, melyekböl csak egyet jutalmaztak. Einstein esetén pontosan ugyanez a helyzet. Söt még abban is hasonlítanak, hogy nem a legnagyobb tudományos eredményükért kaptak Nobel-díjat. Einstein legnagyobb tudományos eredménye a relativitáselmélet kidolgozása volt, mégis a fényelektromos jelenségek (a fotoeffektus) magyarázatáért ${ }^{6}$ kapott fizikai Nobeldíjat 1921-ben.

1947-ben telepedett le az Egyesült Államokban, ahol 1955. február 22-én megkapta az amerikai állampolgárságot, 1956. április 24-én pedig az Egyesült Államok Nemzeti Tudományos Akadémiája tagjává választották. 1947 és 1962 között az Amerikai Egyesült Államok Izomkutató Tudományos Intézete tengerbiológiai laboratóriumának igazgatója volt, ahol a sejtosztódást kiváltó tényezőkkel és ennek nyomán a rák keletkezésének okával kapcsolatos kutatásokat irányította. A rákkutatás meghatározó szaktekintélye lett. Erre családi indíttatása is volt, mert élete nagy szerelme, második felesége, Borbíró Márta, valamint Nelly lánya mellrákban haltak meg. „Azért is dolgozott éjjel-nappal, mert attól tartott, már nem lesz elég ideje ahhoz, hogy megfejtse a rák misztériumát. Amikor megismertem, már tudtam: ö erre tette fel az életét. [26]" - nyilatkozta negyedik felesége Marcia Huston. 1962 és 1971 között a Darthmouth-i Egyetem professzora volt ${ }^{7}$. Professzortársa a szintén magyar származású KEMÉNY JÁNOS

http://www.kaleidoscopehistory.hu

Varga János mérnöktanár 
Kaleidoscope

matematikus volt, aki 1955-67-ig a Matematikai Tanszék vezetője, majd 1970 és 1981 között a föiskola rektora volt. Kettőjük ezen időszakra eső kapcsolata, illetve Kemény ${ }^{8}$ teljes tevékenysége tudománytörténetileg még feltáratlan.

\section{Egyéb tudományos eredményei}

Szent-Györgyi az iskolában egy „nehézfejü” gyerek volt. Anyai nagybátyja ifj. Lenhossék Mihály kiváló anatómus, elismerésre méltó idegrendszeri és antropológiai kutatásokat végzett, akit a Nobel-díjra is méltónak neveztek kortársai, aki szinte nevelőapja volt, egyszerüen „tökfej” -nek nevezte. Albert 16 éves kora körül megtáltosodott, és ekkor döntötte el, hogy kutató orvos lesz. Nagybátyja ezt nem akarta, mert félt a nagyhírü Lenhossék név lejáratásától. Először a kozmetikus-, majd a gyógyszerész-, végül a fogászati szakmát ajánlotta, de a kitünő érettségi bizonyítvány után beadta a derekát. Így felvették az orvosegyetemre, de nagybátyja megígértette vele, hogy proktológus (végbéllel foglalkozó szakember) lesz. E javaslat hátterében saját aranyere állt. „Úgyhogy én a rosszabbik végénél kezdtem az orvosi kutatásaimat." - nyilatkozta később Szent-Györgyi. Nagybátyja intézetében már 1913-ban, húszévesen nívós cikket közölt a végbél anatómiájáról és szövettanáról jóhírü német szaklapban. Később a szemmel kezdett foglalkozni, s e témában is jelentős sikereket ért el. Ezt követően beleszeretett az élettanba. A vele kapcsolatos első írás a The New York Times hasábjain 1933. március 26-án a Tudomány rovatban jelent meg $A$ hang ereje címmel. Arról számolt be, hogy fizikusok és kémikusok egyszerü élő szervezetek, baktériumok és kémiai rendszerek, molekulák viselkedését tanulmányozzák ultrahanggal való besugárzás hatására. A kísérletek szerint a magas rezgésszámú, az emberi füllel már nem érzékelhető hangok rezgései lebontják a keményítőt és a cukrot, hatására apró állatok és baktériumok pusztulnak el, folyadékok felforrnak, és szétbomlanak. „Egyikük Szent-Györgyi Albert professzor, akinek vitaminnal kapcsolatos kutatásai világszerte ismertek. A vezető szerves kémikusok közé tartozik. A Nature-nek írott levelében arról számolt be, hogy ultrahanghullámokat vagy szuperszonikus rezgéseket használt arra, hogy nádcukrot, zselatint, keményítőt, akácmézet, egyaránt egyszerü molekulákká, monoszaharinokká alakítsa. Mindehhez másodpercenként 723 000-szer rezgö kvarclemezt használt. Szent-Györgyi professzor szerint »lehet, hogy az ultrahang rezgései szolgálnak a kémiai kötések erőssége mérésének módszeréül. « Ez alapján SzentGyörgyit a napjainkban népszerü ultrahangos kémia elöfutárának tekinthetjük. [22, 6. o.]”

Szent-Györgyi a börvérzésekkel -un. purpurákkal- járó Henoch-Schönleich-betegség kezelésében is jótékony hatásúnak találta a nyers paprikát. Ennek okát keresve 1933-ban munkatársaival azt a bejelentést tették, hogy a citromhéjban új vitamin található, egy sárga flavinoid anyag, amelyet ök permeábilis (áthatoló, átbocsátó) vitaminnak, vagy $\boldsymbol{P}$-vitaminnak neveztek el, mert a hajszálvérerek (kapillárisok) törékenységének, áteresztőképességének (permeabilitásának) - innen a vitamin elnevezésében a „P” betü és az nem a paprika szóból származik, amint azt Czeizel Endre írja [12, 35. o.]) - szabályozásában vesz részt, és gyógyító hatással van a vérzésükre. [22, 12. o.]. A későbbi tudományos kutatások kimutatták, hogy a P-vitamin azoknak a természetes anyagoknak, a flavonoidoknak nevezett növényi festékek osztályába tartozik, amelyek képesek oxigént váltakozva felvenni és leadni (képesek reverzibilesen oxidálódni és redukálódni), így az élet ,fuvaros brigádjának” a tagjai az oxigén szállításában a szövetekhez. Nem egyetlen tiszta anyag, hanem legalább 3 flavonoid nagyon aktív komplexe. Érdekes, hogy P-vitamin nélkül a C-vitamin nem hatásos a skorbut megelőzésében. A P-vitamin segíti a C-vitamin felszívódását és megvédi az oxidációtól, ezen kívül erősíti a hajszálereket. Később az is kiderült, hogy a

http://www.kaleidoscopehistory.hu

Varga János mérnöktanár 
rákos betegek az eddigieknél erősebb röntgensugárzással is kezelhetők, ha P-vitamint szednek. Később ezt nevezték CVP (citrom flavonoid) terápiának. Negyvenéves korában 1935-ben kezdett kvantummechanikával foglalkozni, meggyőződése volt, hogy az élet titka az elektron körül forog.

1944. febr. 18-án a stockholmi Morgan Tidningen címü újság arról tudósít, hogy Szent-Györgyi Albert az emberi vérben eddig nem ismert alkotórészt fedezett föl, amely a hemofiliát, vagyis az alvadás nélküli vérzésre való öröklődési hajlam kialakulását hozza létre

Intuitív módon kidolgozott egy elméletet - amit később megavitamin terápiának vagy „ortomolekuláris" terápiának is hívtak -, amelynek az volt a lényege, hogy a betegség kifejlődését megakadályozó, illetve a teljesen egészséges állapotot biztosító vitamindózisok között igen nagy a különbség: „A C-vitamin részleges hiányakor a szervezet ellenállóképessége csökken. Az évnek ebben a szakában [télen] jelentkező sok megfázás oka az is lehet, hogy csökken az ellenállásunk. Mivel a C-vitamin most már kristályos formában és megfelelő mennyiségben rendelkezésre áll, ez a kérdés több mint teoretikus jelentőségü. (Szent-Györgyi levele Sir Walter Fletcher brit fiziológushoz, 1933. január. 6.)” Munkatársa LAKI KÁLMÁN így emlékezett vissza: „Jómagam gyakran fáztam meg télen, ezért SzentGyörgyi tanácsára naponta nagy adag C-vitamint kezdtem fogyasztani. [9, 113]" Így saját maga tapasztalata meg jótékony hatását. Később Linus Pauling is javasolta ezt a módszert, de Szent-Györgyi elsőbbsége ebben sem vitatható.

A The New York Times 1954-ben arról tudósít, hogy „Az Amerikai Kardiológiai Társaság SzentGyörgyi Albertnek ítélte az ez évi Albert Lasker díjat.” (A Lasker Díjakat 1945 óta évente adják ki olyan élő személyeknek, akik jelentős mértékben hozzájárultak az orvostudományhoz, vagy akik közszolgálatot végeztek az orvostudomány nevében. A díjakat néha Amerikai Nobel-díjnak nevezik.) Ezt azokkal a kutatási eredményekkel érdemelte ki, amelyeket a szívérrendszeri megbetegedések kutatásában ért el, amelyek a szív elemi fiziológiájának, a szívmüködés jobb megértéséhez vezettek.

A 60-as években megkezdett rákkutatást még életének utolsó szakaszában is folytatta. A professzor majdnem két évtizedet szánt életéből rákkutatására, hitt benne, hogy gyógyítható, ehhez meg akarta ismerni a probléma alapjait. Teljes mértékben meg volt róla győződve, hogy a növényekben kell keresni a rákellenes anyagokat. Éppen ezért kutatásait a búza fú és csíra állapotának szentelte a későbbiekben. Kutatásai során a búzafúben talált alkotóelemeket C-vitaminnal próbálta kombinálni, ami egyes állatkísérletek alapján sikeres megoldásnak bizonyult a rák elleni küzdelemben. Természetesen SzentGyörgyi maga is minden nap fogyasztott C-vitamint búzafüvel kombinálva. Saját bevallása szerint aktivitását és életerejét annak köszönhette, hogy minden reggel magához vette ezt a hatásos kombinációt, amiben biztosan van igazság, hiszen 93 évet élt. Sajnos neki sem sikerült megtalálnia a rák ellenszerét, de kutatásai közben alkalmazott módszere, a biológiai, élettani folyamatok kvantumkémiai megközelítése, a szubmolekuláris biológia, a 21. sz.-ra kiható eredmény, mellyel messze megelőzte korát.

Ebben unokaöccse, SzENT-GYÖRGYI ANDRÁs és felesége voltak legközvetlenebb munkatársai. 1958ban vallotta: ,a kvantummechanikának -a modern fizika matematikájának- fontos, új alkalmazási lehetősége van a szív rendellenességeinek és a rák problémáinak megértésében. Most már tudjuk, hogy az élet nem egyszerü kémiai reakciók sorozata, hanem elektronok ${ }^{9}$ és mozgások keveréke, ezek szerkezete vizes oldatban. $[22,4$. o.]" Az ember képességei a gondolkodásra, a járásra mind elektronokkal 
Kaleidoscope

összefüggő, más néven finomszerkezeti problémák. - jelentette ki egy társasági ülésen a New York-i Orvos Akadémia székházában, ahol Az összehúzódó miokardium (a szívizom latin neve - a szerzö) címmel tartott előadásában.

Szellemi örökségének szép szimbóluma, hogy még halála után is jelent meg hír munkásságáról. Az újság szabadalomfigyelő rovata halála után egy héttel közölte, hogy elfogadták FODOR B. GÁBORral ${ }^{10}$, a West Virginia Egyetem professzorával (szintén a Szegedi Egyetem korábbi professzorával) közös szabadalmukat, amelyet az emberi szervezet immunrendszerét erösitö vegyületekkel kapcsolatban nyújtottak be. A vegyületeket a továbbiakban az Amerikai Biotechnológiai Vállalat, Rockvill, Md. vizsgálja $[22,128]$.

\section{Békeharca, pacifista tevékenysége}

A 60-as évek elején a The New York Times számos olvasói levelét jelentette meg híres Letters to Editor (Levelek a Szerkesztőnek) rovatában, amelyben a nukleáris fegyverkezés, az atomháború, az atom- és hidrogénbombával végzett kisérletek veszélyére hívta föl a figyelmet.1970-ben tudósi tekintélyét is latba vetette, amikor az értelmetlen vietnami háború ellen emelte fel szavát, keményen bírálva az amerikai kormányt. 1970-ben írta a "The Crazy Ape" (magyarul: Az örült majom, 1989) címü híres könyvében írta le az emberiség önpusztításáról, a tudományról, valamint az ember földi túlélésének kilátásairól szóló, pesszimista hangú kritikai eszmefuttatásait, amely máig is a legjelentősebb háborúellenes írások közé tartozik. Könyvének fö gondolata, hogy az emberiség még mindig kőkorszaki reflexek alapján cselekszik, holott már az egész Föld elpusztítására elegendő atomfegyver van a kezében. Elitélte a koreai háborút, a hidrogénbomba kifejlesztését, a vietnami háborút, általában a fegyverkezés ellen harcoló békeszerető humanista volt. Teller Edével több vitája is volt. "Teller a politikai feszültségben és gyanakvásban anyagilag rendkivül érdekelt, politikailag befolyásos és jóformán kimeríthetetlen eszközökkel rendelkezö katonai-ipari-komplexumnak vált a szócsövévé. [...] Úgy látszik képtelen elképzelni, hogy az embereket időlegesen szétválasztó szakadékok fölé hidat lehet emelni." - írta róla az 'Egy biológus gondolatai' c. könyvének Teller könyvére utaló 'Hirosima legendája' című fejezetében. A The New York Times-ban 132 kisebb cikket (szerkesztőségi levelet) írt, melyekben minden aktuális politikai, emberi stb. kérdésben kifejti kritikus véleményét. E cikkeinek gyüjteménye nemrég jelent meg magyarul Szegeden, [22]. Még ahhoz is vette a bátorságot, hogy le „öreg idiótázza” a világ háborúskodó vezetőit. John F. Kennedyvel ${ }^{11}$ viszont jó viszonya volt, az elnök még meg is látogatta tengerparton fekvő szépfekvésủ rezidenciáján (Seven Winds - Hét szél), ahol sokszor adott partikat, melyeken sok híresség, többek között barátja Neumann János is részt vett. „A legpompásabb emberi elme, amellyel valaha is találkoztam, barátomé, Neumann Jánosé volt." - vallotta róla. Ekkoriban írta '15 perc zéróig' címü hatásos cikkét is, amelyben sürgette az USA és a Szovjetunió közötti fegyverkezési verseny leállítását, mert különben az emberiség belátható időn belül elpusztítja önmagát. Hangoztatta, hogy „... a fegyverekre szánt pénzt az oktatásra és az egészségügyre kell költeni." Amikor a Sorbonne egyetem díszdoktorrá nevezi ki, munkásságát e szavakkal méltatják: Szent-Györgyiben nem csak a nagy kutatót tisztelhetjük, akinek munkássága, illetve felfedezései Louis Pasteurhöz hasonlóan, új utat nyitottak több tudományterületen is ${ }^{12}$, hanem az emberiség nagy barátját is.

http://www.kaleidoscopehistory.hu

Varga János mérnöktanár 
Gyakran fellépett LiNUS PAULINGgal ${ }^{13}$, aki az atomfegyver kísérletek egyik legnagyobb tudós ellenzője volt Amerikában. Alkalmanként leveleztek is. 1961. október 16-án az alábbi levelet írta neki.

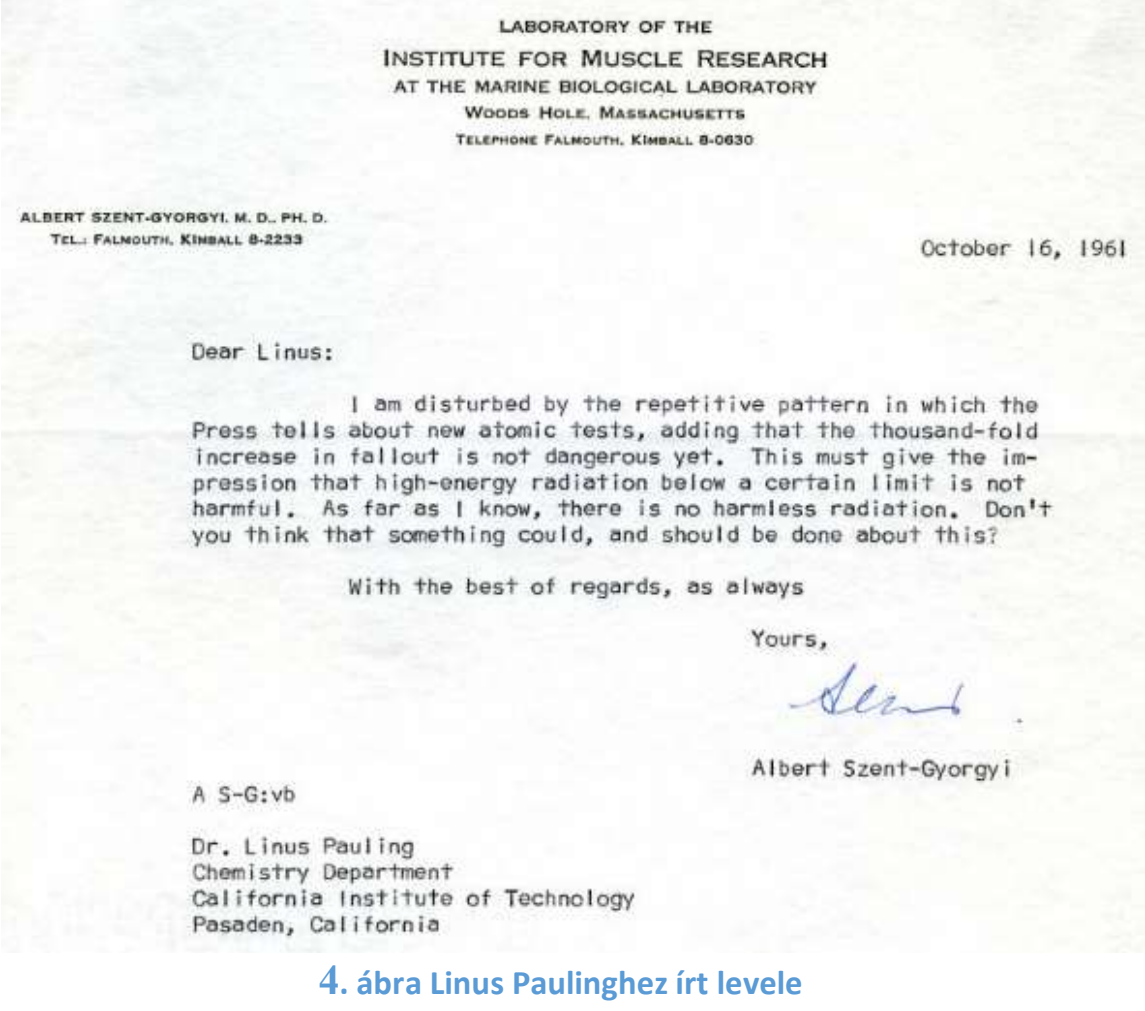

ALBERT SZENT-GYÖRGYI, M. D. PH. D.

Tel.: FALMOUTH, KIMBALL 8-2233 October 16, 1961

Dear Linus:

I am disturbed by the repetitive pattern in which the Press tells about new atomic test, adding that the thusand-fold increase in fallout is not dangerous yet.

This must give the impression, that high-energy radiation below a certai limit is not harmful.Don't you think, that something could, and should be done about this?

With best of regards, as always

Yours,

A S-G:vb

Albert Szent-Györgyi

Dr. Linus Pauling

Chemistry Department

California Institute of Technology

Pasadena, California

http://www.kaleidoscopehistory.hu

Varga János mérnöktanár 
Kedves Linus!

Nagyon zavar az az ismétlödö motívum, amelyikben a sajtó beszél az új atombomba tesztekröl, hozzátéve, hogy még az 1000-szeres radioaktív szennyezés (kihullás) sem veszélyes. Azt a benyomást kelti, hogy bizonyos határ alatti nagy-energiájú radioaktív sugárzás nem káros. Amennyire én tudom, nem létezik ártalmatlan sugárzás.

Nem gondolja, hogy valamit lehetne, és kellene tenni ezzel kapcsolatban?

\section{Szivélyes üdvözlettel, mint mindig}

\section{Szent-Györgyi Albert (a szerzö forditása)}

Hozzájuk hasonló, vagy talán még nagyobb aktivitást fejtett ki SzILÁRD LEÓ, aki szinte emberfeletti munkát végzett a nukleáris kísérletek betiltása, az atomfegyverek elterjedésének megakadályozása, az ellenörzés fontossága, a nukleáris háború veszélyének elhárítása, az atomenergia békés felhasználása, a békemozgalmak létrehozása és müködtetése, a két nagyhatalom - a volt SZU és az USA-atomtudósai együttmüködésének megszervezése, a fegyverkezési verseny politikai megoldása terén, akit nyugodtan nevezhetnénk a béke örének. Hármójuk között egyenlő arányban megosztott béke Nobel-díj adományozása igazságos döntés lett volna, de sajnos csak Linus Pauling, német származású amerikai kémikus kapta meg 1962-ben ${ }^{14}$. Életrajzírója szerint Albert reménykedett benne, hogy esetleg a következő évben ö lesz a díjazott, de erre nem került sor.

\section{Einstein és Szent-Györgyi}

A nukleáris kísérletek betiltása, a nukleáris háború veszélyének elhárítása terén, és még sok egyéb vonatkozásban -mint például a boldogság fogalma, a könyvek szerepe, az iskola/oktatás feladata stb.teljesen azonos véleményen volt, mint Einstein. Még a pipát is ugyanazon az oldalon szívták. (Lásd a fotókat.) Nem véletlen, hogy halálakor őt kérték fel nekrológjának megírására, melyben így jellemezte tudóstársát: „Senki sem képviselte jobban a tudás, az erkölcs és az etika nagy egységét, mint Einstein. Ezért Einsteint az emberiség egyik nagy erkölcsi vezetőjének tartom, és azt kivánom, hogy a világ ne csak azt tanulja meg töle, amit a fizikának adott, de azt is, amit humanistaként képviselt." Az emberiség jövőjét illetően pesszimista volt: „Az emberiség az atomerő birtokában, kapzsisággal, félelemmel és hatalomvággyal szívében, önmaga elpusztítására ítéltetett. [...] a bombákat senki sem lőheti ki anélkül, hogy ne követne el öngyilkosságot, és ne pusztítaná el vele magát az emberiséget. [5, 18. o.]” „Vagy alkalmazkodunk az új helyzethez, átalakítjuk gondolkodásmódunkat és emberi viszonyainkat, valamint a dicsőségről, az erőről, az uralkodásról, a kizsákmányolásról vallott elavult eszméinket a kölcsönös megértésre, a tiszteletre, segítségnyújtásra és együttmüködésre cseréljük, vagy elpusztulunk. Jelenleg a kihalás felé tartunk, és ki fog könnyeket hullatni értünk? [22, 120. o.]” Vallotta, hogy: ,az emberi élet nem pusztítással, hanem alkotással tehető tartóssá. Élvezetessé az egészség, boldogság, szépség és tudás teheti."

http://www.kaleidoscopehistory.hu

Varga János mérnöktanár 
Kaleidossope

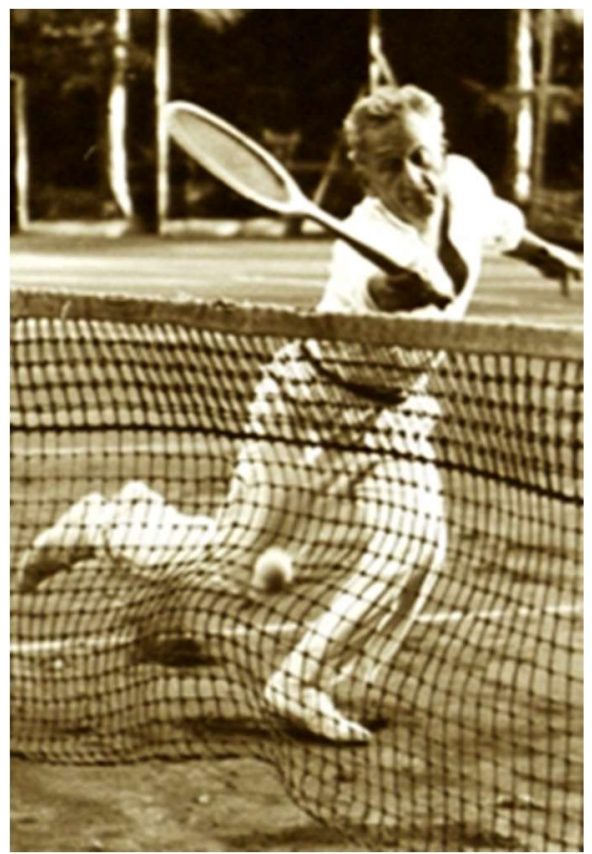

5. ábra a sportember a 30 -as években ${ }^{1}$

Már apja is jeles sportoló, kiváló futó volt, de Albert túltett rajta. Teniszezés, lovaglás, autózás (Buick), vitorlázórepülés, motorbiciklizés, kerékpározás, úszás, kajakozás, vízisízés (70 éves korában!), horgászat, vitorlázás, alpinizmus, röplabdázás, mind érdekelte. Emellett ráadásul még kiválóan sakkozott is. (Első felesége DEMÉNY KoRNÉLIA kitűnő teniszező, a Délvidék teniszbajnoka volt.) Az új, erősen jobboldali Gömbös-kormány kultuszminisztere, HóMAN BÁLINT 1932-ben elözetes bejelentés nélkül látogatást tett a „,prof” intézetében, de ő nem tudta fogadni, mert az intézeti röplabdacsapat tagjaként éppen az egyetem bajnokságban volt mérkőzése. 91 éves volt, de még mindig élt benne a régi sportember: egy déltengeri vitorlástúrán (1984 telén) a hajóból hátra szaltót ugrott a vízbe. Amerikában, amikor a tengerparton élt, naponta háromszor úszott. Nem sokkal a halála előtt, 93 évesen is vágyott erre, pedig ekkor már felesége tolószékben vitte le az óceánig és ő még akkor is úszott. Lánya Kornélia (a kis 'Nelli') is sportszerető, a magyar síválogatott tagja volt.

A művészeteket is kedvelte, különösen a színházat. Saját magáról karikatúrát is készített. Ö maga is írt verseket. Magyarul ezek egy része a már említett 'Az örült majom' c. könyvének mellékletében találhatók. Ezek közül a legismertebb

15-6 ábra képanyaga SZTE szívességből: Szegedi Tudományegyetem (SZTE) Klebelsberg Könyvtár, Szent-Györgyi Albert gyüjtemény engedélyével.

http://www.kaleidoscopehistory.hu

Varga János mérnöktanár 


\section{Psalmus humanus}

\section{HATODIK IMÁDSÁG: GYERMEKEINK}

Uram!

Elválasztottad a férfi és a női nemet, hogy egymás keresésében

Énünk legmélyebb húrjai rezdüljenek meg a legmagasabb harmóniákban.

Ebből a kölcsönös keresésből fakadnak

Kik tiszta és ártatlan lélekkel születnek.

$$
\text { gyermekeink, }
$$

És én megtanítom őket félni és gyülölni, Megtöltöm elméjüket balhiedelmeimmel, Míg az óvóhelyek az élet kietlenségét és a jóigyekezet hiábavalóságát hirdetik,

$\mathrm{S}$ mikor felnőnek, s készek nagy és nemes cselekedetekre,

A szervezett tömeggyilkolásra tanítom őket,

Erkölcsi és szellemi tespedésben pocsékolva el

$$
\text { éveik javát. }
$$

Isten! Óvd meg gyermekeimet!

Óvd meg elméjüket, hogy az én romlottságom öket meg ne rontsa.

Óvd meg életünket, hogy a fegyverek, melyeket kovácsolok, őket el ne pusztítsák,

Hogy különbek legyenek szüleiknél, és felépítsenek egy új és jobb világot ${ }^{15}$,

Egy világot tele szépséggel, tisztességgel és

Hogy szeretet és béke uralkodjon, jóakarattal, Mindörökké.

(Ez a szövegváltozat megegyezik egy Szent-Györgyivel készült rádióinterjúban elöadott szöveggel, amelyben maga a tudós mondja el saját versét. Az örült majom $c$. kötetben helyenként kis eltéréssel ugyan, de más szöveg szerepel, de ez a szövegváltozat nyelvtanilag és irodalmilag is helyesebb. - a szerzö)

Az irodalomról, a művészetekről és a színjátszásról úgy vélekedett, mint a tudományról: azt mondta, meg kell élni. Az egyetemen színjátszókört alapított, melynek egyik előadásában sikeresen fellépett a budapesti Nemzeti Színházban is. Első felesége válásuk után a közép-amerikai népek müvészetével foglalkozott. Édesanyja muzikális volt, nagyon szép hangja miatt a család kieszközölt egy meghallgatást Gustav Mahlernél, a budapesti opera akkori karmesterénél, de az nem tartotta hangját elég erősnek ahhoz, 
Kaleidoscope

hogy mủvészeti pályára menjen, inkább a házasságot ajánlotta. Nagyon jó ajánlat volt, ennek köszönhető később egy Nobel-díjas gyerek. Testvére Szentgyörgyi Pál (1890-1972) a jogi doktorátus mellett a zeneakadémiát is elvégezte. Amíg a hallása meg nem romlott, Albert is szeretett zenét hallgatni.

\section{Diplomáciai tevékenysége - A kém}

1940-től reformjai és antifasiszta magatartása miatt sajtótámadások érték. 1942-től egy antifasiszta ellenállási mozgalom vezetője lett. A II. világháború végjátékában kémregénybe illő cselekmények szereplőjévé vált. Szent-Györgyi Albertet -kitünő angol kapcsolataira építve- Isztambulba küldték, ahol titkos diplomáciai küldetésének célja Magyarország háborúból való kiugrásának előkészítése volt. Öt nem a kormány, hanem a rendszer baloldali ellenzékének különböző pártjai és irányzatai küldték Isztambulba. Előbb találkozott Kállay Miklóssal, akit tájékoztatott küldetéséről, aki jóváhagyta, hogy Isztambulban tárgyaljon a britekkel Magyarország második világháborúból történő kiugrásáról és megkérte, hogy tájékoztassa az Egyesült Államok ankarai nagykövetét a következőkröl.

„1. egyetlen katonát vagy fegyvert sem ad többet Németországnak; 2. ö jelenleg és a jövőben is kiabálni fog a zsidók ellen, de a gyakorlatban nem tesz semmit, és 70.000 menekült zsidót bujtogat az országban; 3. jelenleg még nem tud más politikát folytatni, mert az esetben Magyarországot megszállnák a németek, totálisan mozgósitanák a szövetségesek ellen, és a zsidókat kiirtanák. [13, 18. ]" Alkalmasnak gondolta magát a háborúból való kiugrás és a demokratikus átmenet levezénylésére. Ahhoz képest, hogy semmiféle politikai tapasztalattal nem rendelkezett, ez elég nagyfokú önbizalomból árulkodott. Kállay Szent-Györgyivel üzent a briteknek: kész bármikor átállni, de az országban állomásozó német csapatok miatt ezt nehéz meglépni. Szent-Györgyi találkozott a brit titkosszolgálat törökországi vezetőjével. Tárgyalásai során elég ügyetlenül viselkedett, mert a brit megbízottak mellett olyan „közvetítőkkel” is tárgyalt, akik a német titkosszolgálat ügynökei voltak. Odáig ment, hogy egy amerikai közvetítőnek expozét adjon át, amelyben Magyarország egyenesen felajánlja az ellenségnek, hogy titkos katonai együttmüködést létesít Angliával és Amerikával, mihelyt Németországnak az invázióval kell szembe néznie. Magyarország abban a pillanatban megnyitja kapuit a szövetséges haderők előtt. Szükségesnek tartotta a horthysta kormányzati rendszer megbuktatását, a szövetséges megszállást, egy demokratikus Magyarország megteremtését.

A brit külügyminisztérium igen nagy jelentőséget tulajdonított Szent-Györgyi missziójának. Olyan személyiségnek látták, ,, akivel megfelelö földalatti csatornákon hasznos lehetne diszkrét kapcsolatok fenntartása. [13, 19. ]" A tudós azt a feladatot kapta, hogy térjen vissza Budapestre és segítsen egy rádiókapcsolat kiépítésében a londoni adminisztráció és Kállay Miklós között. A rádiót állítólag barátja Bay Zoltán fizikus készítette el, aki emiatt szintén veszélybe került és bujdosnia kellett, mert a tervet a Gestapo megtudta, és megakadályozta, így a rádiós kapcsolat nem jött létre [9, 122]. Ezek a Harmadik Birodalom tudomására jutott információk szolgáltatták részben az okot ahhoz az 1943 öszére megszületett döntéshez, hogy a háborúból való kiugrás megakadályozása céljából Magyarországot katonailag meg kell szállni. Az 1944. március 19-i német megszálláskor kénytelen volt illegalitásba vonulni. Egyes források szerint Hitler személyesen adott parancsot az elfogatására, és a Gestapo mindent elkövetett kézre kerítése érdekében. A tudós ezt később egy televíziós interjúban „élete csúcspontjaként” emlegette. A valóság viszont az, hogy Hitler Szent-Györgyi útját, mint Kállay miniszterelnök hütlensége bizonyítékának tekintette. A feljegyzésekböl világosan kiderül: „Hitler sem 1943-ban, sem 1944-ben nem rohant ki SzentGyörgyi ellen, nem követelte kiadatását, mert nem tekintette politikai tényezönek. [9, 121]" Szent-Györgyit

http://www.kaleidoscopehistory.hu

Varga János mérnöktanár 
Kaleido scope
Journal of History of Culture, Science and - Tudomány- és Orvostörténeti Folyóirat

DOI: $10.17107 / \mathrm{KH} .2020 .20 .89-118$

1944-ben egy német razzia előtt svéd segítséggel az utolsó pillanatban menekítették ki a nácik - konkrétan a Gestapo - elől Budapestről és csempészték át már szovjet ellenőrzés alatt álló területre. Budapest elfoglalása után Molotov személyes utasítására Malinovszkij marsall vigyázott rá enyingi főhadiszállásán. V. Gusztáv svéd király saját hatáskörben svéd állampolgárságot adományozott Szent-Györgyinek és feleségének. (Sokáig svéd útlevéllel utazott a háború után.) 1945 januárjában egy szovjet különítmény igyekezett a tudós segítségére, és családjával Moszkvában kapott menedéket. A svéd segítséget és moszkvai megérkezést a The New York Times is érdemesnek tartotta arra, hogy írjon róla.

\section{Tudománypolitikai és kultúrdiplomáciai tevékenysége}

Szent-Györgyi Albert a második világháború után kiépülő új Magyarországon a politikai demokrácia megteremtését elképzelhetetlennek tartotta nemzetközi szintü tudományos élet nélkül. Nemzeti felemelkedésünk és kibontakozásunk zálogát a világszinten művelt tudományban látta. Modellértékűnek az amerikai és angol tudományos életet tartotta, de a modernizált tudományos életbe minden értéket integrálni kívánt, ezért a szovjet tudomány igazi értékei és a szomszéd országok valódi eredményei számára egyaránt fontosak voltak. A tudomány és a politika együttmüködésének számára csak addig volt értelme, amíg az a demokrácia talaján állt, amíg a politika a tudomány és a kutatás szabadságát nem sértette. Szent-Györgyi Albert a természet- és müszaki tudományok súlyának növelését és a humán tudományok befolyásának csökkentését tekintette a modernizáció központi kérdésének.

Az MTA új vezetője Kornis Gyula filozófus ${ }^{16}$ lett, aki az Akadémiát demokratikus intézménynek tartotta, annak modernizálását a régi keretek között, alapvető strukturális változtatások nélkül is megoldhatónak vélte. A megtisztuláshoz elégségesnek találta a háborús bünösök eltávolítását, és mintegy ötven új tag bevonását. Szent-Györgyi viszont úgy ítélte meg, hogy egyes politikailag kompromittált tagok kizárása nem oldja meg a problémát, hanem az Akadémiának az új feladatok elé került tudomány alapvető igényeinek megfelelően kell megújhodnia. Mihelyt

A Magyar-Szovjet Baráti Társaság alapító tagja, pártonkívüli meghívott parlamenti képviselő lett; pártnak egész élete során soha nem volt tagja. 1947-ben - mivel úgy látta, hogy a politika szakított a demokráciával és a tudomány szabad fejlődése veszélybe került, a kommunista párt egyre növekvő hatalma az általa képviselt értékeket és személyes szabadságát is veszélyezteti - Szent-Györgyi a legnehezebbet, az emigrációt is vállalta. Svájci szabadságáról az Egyesült Államokba utazott. Érdekesség, hogy 1948-ban még megkapta az akkor első alkalommal kiosztott Kossuth-díjat. (Amerikában a massachusettsi Woods Hole-ban telepedett le, az Oceanográfiai Intézet számára létrehozott izomkutató laboratóriumban folytatta munkáját. Főként a sejtlégzéssel, izom-biokémiával, biogenetikával és rákkutatással foglalkozott.)

\section{A nőimádó}

Nagy tisztelője volt a női nemnek, de nem volt szerencséje a nőkkel. Négyszer házasodott meg, és kettősség jellemezte Szent-Györgyi Albert nőkhöz való viszonyát - utal egyik unokája, Lesley véleményére az életrajzíró, Ralph W. Moss. Egyfelől csak a külsőjüket értékelte, és férfisoviniszta módra viselkedett velük, másfelől szinte uralkodtak rajta azok a nők, akikkel együtt élt.

http://www.kaleidoscopehistory.hu

Varga János mérnöktanár 

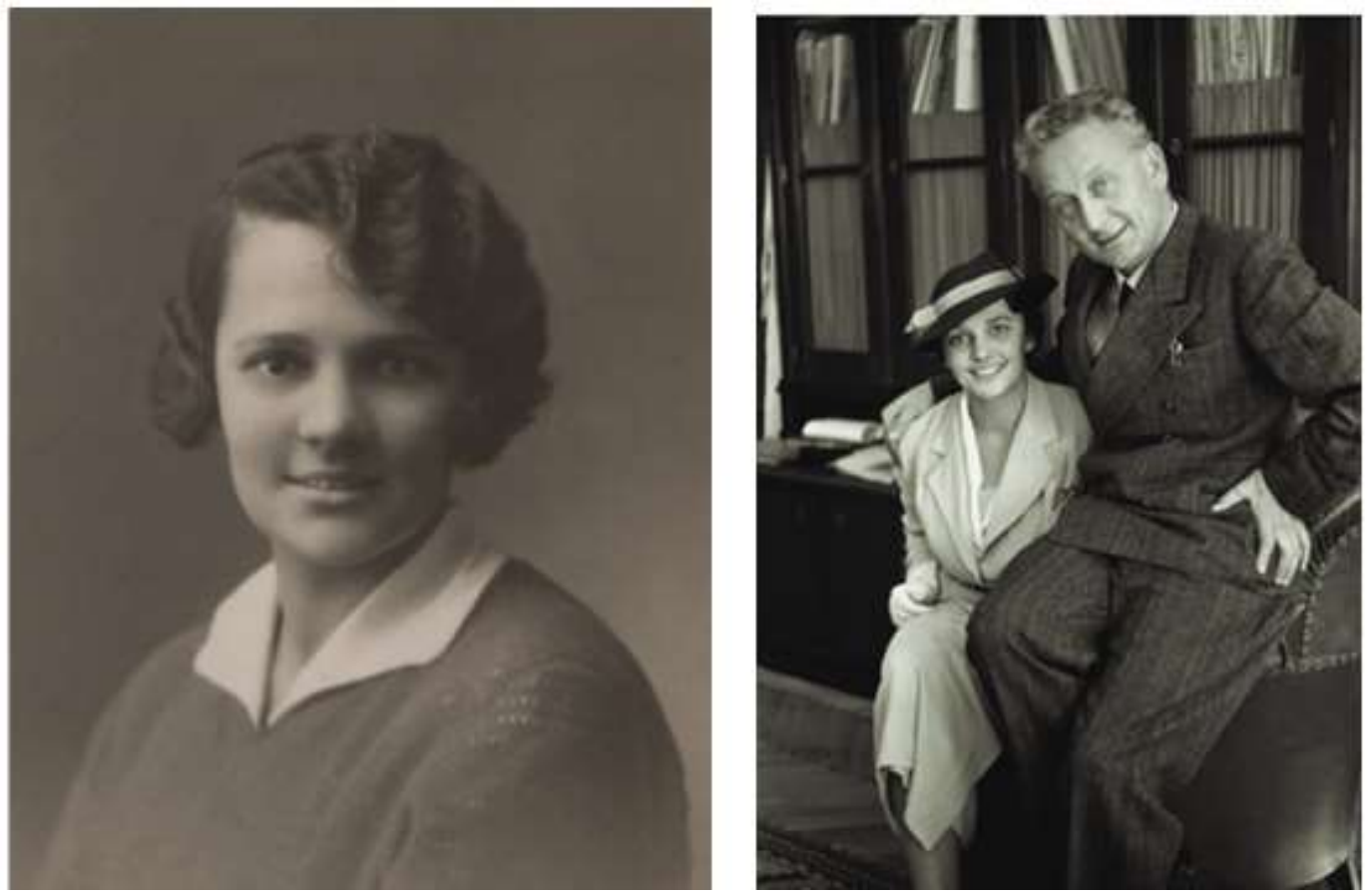

6. ábra Demény Kornélia (1898-1961), házasság:1917-1938)²

Első felesége DEMÉNY KoRnÉlia (a postaügyi miniszter lánya) párját ritkító tenisz tehetség, ugyanakkor gyönyörü és okos nő volt, aki Budapesten a BBTK-ban játszott, Szegeden pedig ötször nyerte meg Dél-Magyarország bajnokságát. 1917-ben, 24 évesen vette feleségül. Kornélia (a „nagy” Nelli) akkor 19 éves volt. Bay Zoltán fizikus, aki itthon és Amerikában is Szent-Györgyi legközvetlenebb barátja volt, nyilatkozta róla: „nála szebb és intelligensebb növel egész életemben nem találkoztam.”

Felesége kutatási asszisztensként dolgozott mellette Szegeden, de önálló ötleteit férje nem nagyon tolerálta. Kapcsolatuk végét Kornélia leszbikus hajlamainak kiderülése okozta. 21 évvel később 1938-ban Szent-Györgyi előadói körúton volt az Egyesült Államokban, felesége is vele tartott, de nem tért vissza. Többet nem is találkoztak, 1941-ben váltak el. Volt felesége Cornelis St. George-ra változtatta a nevét és jól menő építési vállalatot alapított. Váratlan szívrohamban halt meg1961-ben, éppen akkor, amikor a kis Nelli a családjával az Egyesült Államokba költözött, hogy együtt lakjanak. Ekkor apjához csatlakozott Woods Hole-ba. 1969. szeptember 21 -én, 51 éves korában emlőrákban halt meg.

\footnotetext{
2 25-6 ábra képanyaga SZTE szívességből: Szegedi Tudományegyetem (SZTE) Klebelsberg Könyvtár, Szent-Györgyi Albert gyüjtemény engedélyével.
}

http://www.kaleidoscopehistory.hu

Varga János mérnöktanár 
Kaleidoscope

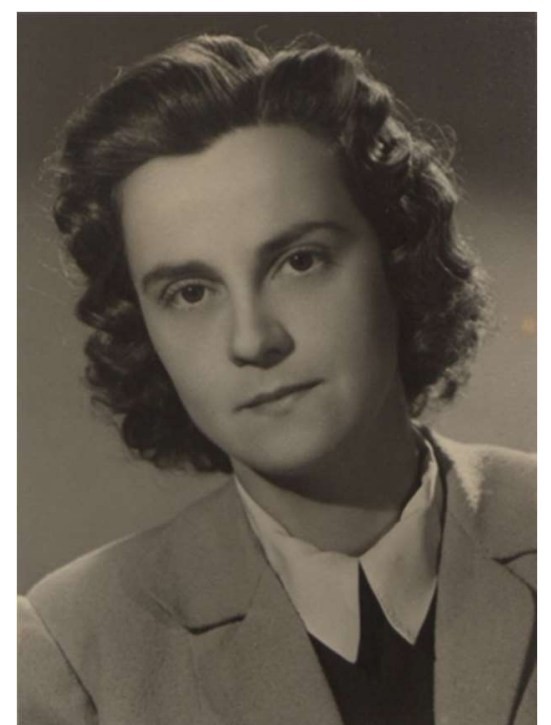

7. ábra Borbíró Márta (1910-1963), házasság:1941-1963, SZTE szívességéből

Második felesége a szabadkai származású BORBíRÓ MÁRTA VOLT, aki megismerkedésükkor két gyerekes asszony volt, dr. Miskolczy Dezsőnek, az országos hírü kolozsvári ideg- és elmegyógyász professzornak volt a felesége. Az 1941. október 18-án kötött házasságuk nagy botrányt kavart. (1941 különös dátum a tudós életében. Ebben az évben válik el első feleségétől, házasságot köt második feleségével, és ebben az évben született későbbi negyedik felesége az Egyesült Államok délnyugati részén, az Oklahoma államban lévő Tulsa városban.) Huszonkét évet éltek együtt nagy szerelemben. A munkában is társak voltak. Második feleségénél rákot diagnosztizáltak, 1963-ban hunyt el. Nem véletlen, hogy SzentGyörgyi ekkortájt már rákkutatással foglalkozott. Közös gyermekük nem született, de Márta két gyermeke később hozzá költözött Woods Hole-ba. Kettejük életét, amíg Mártánál nem diagnosztizálták a rákot, megszépítette, hogy a 'kis Nelli' 1961-ben Afrikából Amerikába érkezett férjével, Geoffrey Pollittal és három gyerekével együtt. Unokái - Michael, Lesley és David - örömöt hoztak az idős Szent-Györgyi életébe, végre igazi családapa lehetett. Aztán a Felker lányok hoztak fényt az életébe: a távoli rokonként jelentkező Tündével és Csillával nem volt intim kapcsolata a hetvenen túli tudósnak, de egy házban éltek, mindenhova elkísérték.

http://www.kaleidoscopehistory.hu

Varga János mérnöktanár 


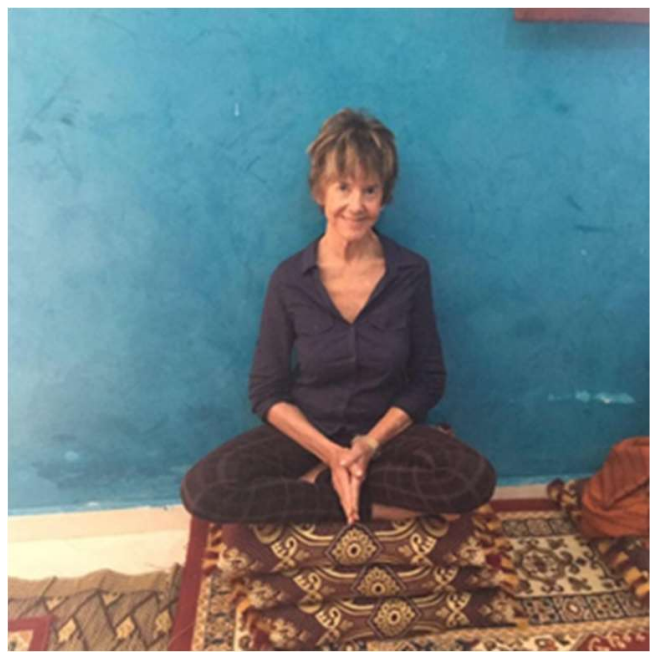

8. ábra Susan Wichterman (1941-) jógaoktató, házasság: 1965-1968)

Harmadik felesége egyik kollégájának, a Pennsylvania Egyetem professzorának 24 éves lánya, a nála 48 évvel fiatalabb SUSAN WiCHTERMAN volt, akit 1965-ben, 72 évesen vett feleségül. A Felker lányok hatására Szent-Györgyi meggyőződésévé vált, hogy egy vonzó és fiatal feleséggel férfiasságát, töretlen erejét is bizonyíthatná. A tudós ajánlatára összeházasodtak, de a kulturális és generációs szakadék áthidalhatatlannak bizonyult, végül Szent-Györgyinek veszekedések után, pénzzel sikerült „kiváltania" magát és kapcsolatuknak 1968-ban válás lett a vége. Szerző 2018.04.02-i megkeresésére Susan 2018.05.09-én kelt levélben ezt írta:

„Dear Janos, I apologize for the delay. I am not particularly computer literate and much too busy for living in the slow pace of Mexico. Yes... I was married to Dr. Szent-Gyorgy from 1965-68. I do not feel comfortable sending much about our lives together until I know more about you and what exactly you are writing. The BBC came to our home in Woods Hole and did a documentary on our life. That still might be available to you. Yes...I have been a student/teacher of yoga for 50 years. I continue to teach.

Sincerely,

Susan Wichterman"

Avagy a szerző fordításában: Tisztelt János, elnézést kérek a kései válaszért. Nem vagyok különösen járatos a számítógép kezelésben és igencsak csendes életet élek Mexikóban... Igen ... 196568 között Szent-Györgyi felesége voltam. Nem lenne helyes, hogy többet irjak közös életünkröl, amíg nem tudok többet Önröl, és hogy pontosan mit is irna. A BBC meglátogatott Woods Hole-i otthonunkban, és dokumentumfilmet készitett életünkröl. Ez még mindig elérhetö. Igen...az utóbbi 50 évben a jógamódszerek tanulmányozásával és oktatásával foglalkoztam. Továbbra is tanitok.

Tisztelettel,

Susan Wichterman

Remélem, hogy ez a megkezdett levelezés folytatódni fog, és a távinterjú nyomtatásban is megjelenik.

http://www.kaleidoscopehistory.hu

Varga János mérnöktanár 

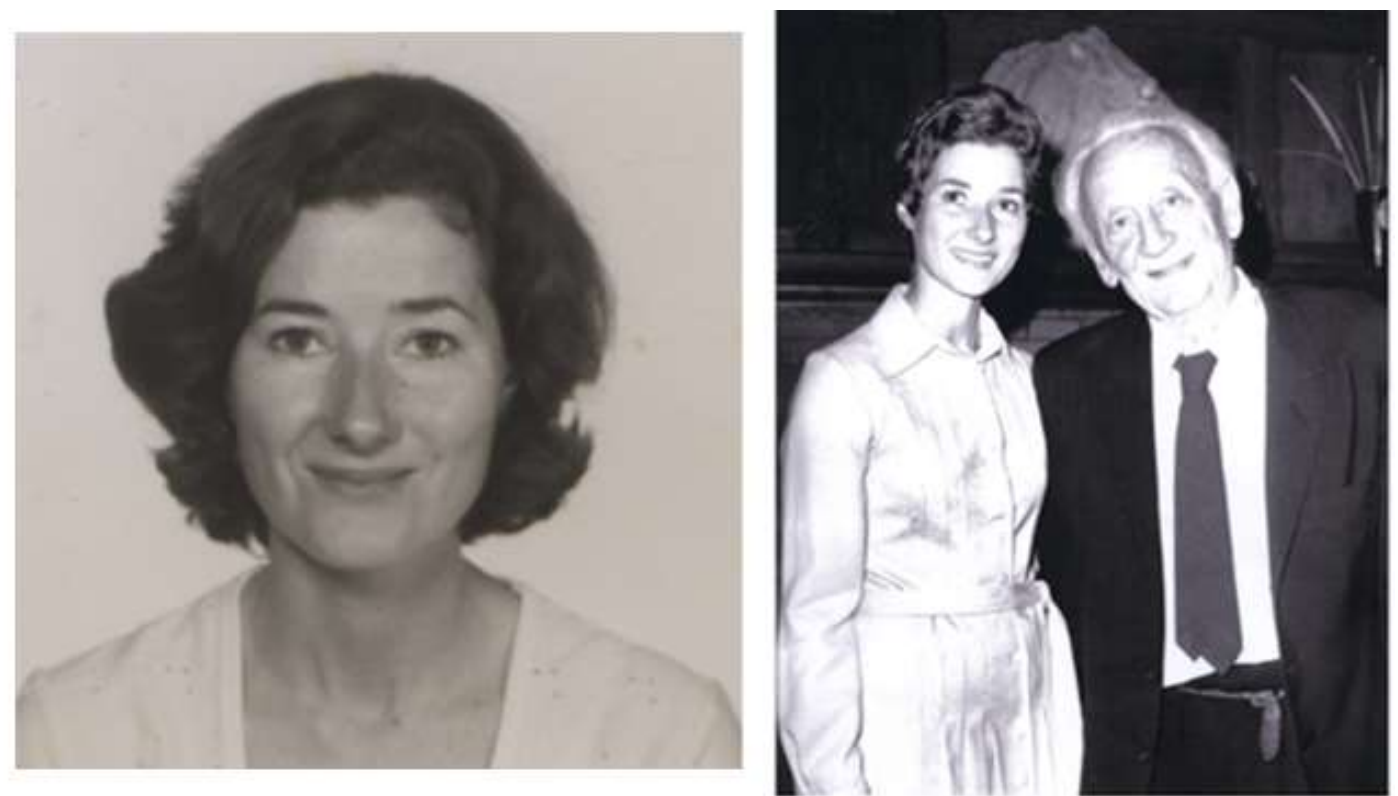

9. ábra Marcia Houston (1941-), festőmúvész, házasság: 1976-1986) SZTE szívességéből

Negyedik felesége MARCIA Houston festőművész volt, aki művészetet tanult. Diplomáját kimagasló eredménnyel a San Francisco Art Institute-on kapta. 1941-ben született, egy gyermekes elvált asszony, akit 1976-ban, 83 éves korában vett feleségül. Marcia ekkor 35 éves. (Boldogságát tetézte, hogy ugyanebben az évben az amerikai delegáció tagjaként hazakísérte a magyar koronát az Egyesült Államokból.) Szent-Györgyi tehát igazi magyar volt, nem engedett a 48-ból, utolsó két felesége 48 évvel volt fiatalabb nála. „Ezen lehet elképedni, kajánul mosolyogni, a nagy vagyon reményében asszonyi számításra tippelni, vagy megfordítva: a megvásárolt szerelmen élcelődni, irigykedni, vagy sajnálkozni, egyszóval minden lehet, csak nem illik és nem érdemes. Mert a valóság egy nő és egy férfi kapcsolatában mindig más, mint amilyennek kívülállóként látjuk, vagy látni akarjuk. Magunkból, környezetünk szokásaiból indulunk ki, ha különösnek, már-már hihetetlennek találunk valamit, ami más, mint amit eddig tapasztaltunk. De ebben a történetben a szereplők is különösek. [26]" Csapó Árpád (1918-1981) szülésznőgyógyász orvos, Szent-Györgyi volt szegedi tanítványa mutatta be neki St. Luisban, hogy fessen róla képet. Marcia az Amerikai Tanító Gárda tagjaként St. Louis szegény negyedében, egy általános iskolában tanított, ahol Árpád kislánya Csapó Marika is tanítványa volt. Innen az ismeretségük. Karcsú, légies és törékeny, melegszívü asszony, tehetséges festő. A lénye olyan áttetsző, mint a valódi kínai porcelán. „Sem Albertnek, sem nekem nem kellett lemondanom semmiröl, csak azért, mert egymásra találtunk. Én semmi más, csak jó felesége próbáltam lenni. Szerettem, gondoztam, és megtettem mindent, amire szüksége volt. Intéztem az utazásait, a vendégek fogadását, rendeztem a publikációit, vezettem a naptárát, egy személyben voltam az asszonya, titkárnője, soförje és barátja. .. a szellemiségével, tudásával, kedvességével, munkabirásával, életszeretetével feledtetni tudta a korát. ... az biztos, hogy hozzá hasonló embert nem találok. Nem tudok megválni az emlékétól. [26]"

Marciaval kötött házassága miatt veje és három unokája elköltöztek Woods Hole-ból.

Marcia jelenleg egy számítástechnikai cégnél konzultáns, ahol orvostechnikai programokat készítenek. Amikor Albertet a szegedi egyetem díszdoktorává avatták az ünnepség zárásaként régi kedves helyén az Alabárdos étteremben rendezett fogadáson csak egy kívánsága volt: Velem szemben egy szép nő üljön!

http://www.kaleidoscopehistory.hu

Varga János mérnöktanár 


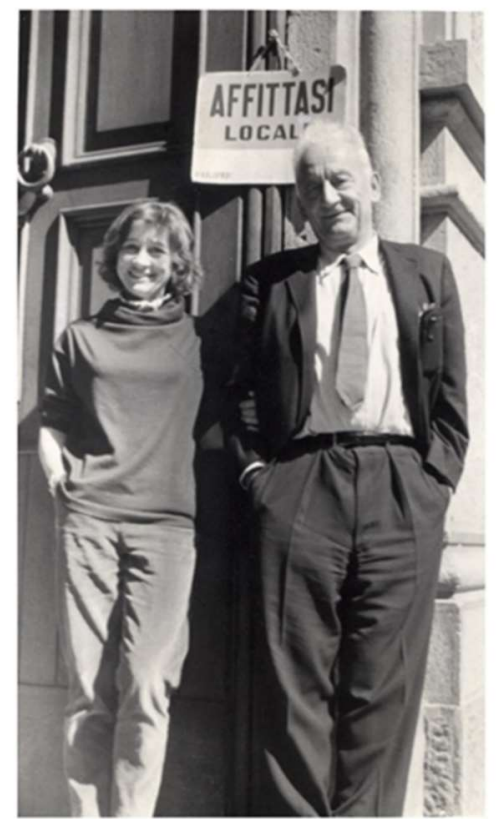

10. ábra Apa és lánya. Szent-Györgyi Nelli (1918-1969)

Első házasságából 1918. október 3-án megszületett egyetlen gyermekük Kornélia, a „kis” Nelli, aki Cambridge-ben, majd Svájcban végezte tanulmányait. 1944-ben férjhez ment, de 1946-ban már el is váltak. Ezt követően a magyar síválogatott tagjaként Ausztriában versenyzett, majd disszidált. 1947. június 12-én összeházasodott egy korábbi angol barátjával. Három gyerekük született, mind a rodéziai Salisburyben (ma Zimbabwe). A család 1961-ben az Egyesült Államokba költözött, Nelli itt halt meg 1969. szeptember 21-én mellrákban. A három unoka jelenleg is az Egyesült Államokban él. Szerintük Marcia Houston éket vert a tudós és családja közé. Gondoskodott a tudósról, de „falat épített" köré, s minden földi vagyonát örökölte. Ennek ellent mond az, amit Marcia a László Ágnesnek adott interjúban mondott. Nem hagyott hátra semmi vagyont „Csak azt a Woods Hole-i házat, amiben ő negyven évig élt. Minden más pénzét, jövedelmét a rákkutatás elleni alapítványba fektette be. S ez így van jól. [26]" SzentGyörgyi örökbe fogadta Marica kilencéves lányát, Lolát, és kizárta végrendeletéből saját, három unokáját. Második felesége és édeslánya, Kornélia (Nelli) rákban halt meg.

\section{Néhány fontosabb gondolata}

Nevelésről: A tanulás és a nevelés nem egyéb, mint az agy programozása. Az emberiség jövője a neveléstől függ, [...] a nevelés az emberiség egyik legfontosabb tevékenysége. [12/39o.]

Tanitásról: Jó tanítás csak ott folyhat, ahol él a kutatás szelleme, az igazságok lelkes, pártatlan szeretete. Tudományos kutatómunkánkkal hazafias kötelességünket is teljesítjük, mert hiszen éppen a tudomány, a

http://www.kaleidoscopehistory.hu

Varga János mérnöktanár 
kultúra az az egyetlen terep, amelyen a versenyt a nagy nemzetekkel egy kis nemzet is felveheti, megcsillogtatván nevét az emberi történelemben.

Iskoláról: Az iskola dolga, hogy megtanítsa, velünk hogyan kell tanulni, hogy felkeltse a tudás iránti étvágyunkat, hogy megtanítson a jól végzett munka örömére és az alkotás izgalmára, megtanítson szeretni, amit csinálunk, segítsen megtalálni azt, amit szeretünk csinálni!”

Könyvekről: Az egész oktatásügyet az egész világon mindenütt, amerre csak jártam, egy nagy tévedés hatja át, egy óriási tévedés. Azt hiszik, hogy a könyvek azért vannak, hogy az ember a tartalmát belepréselje a fejébe. Nézetem szerint a fej gondolkodásra való, a könyvek pedig arra, hogy megtartsák magukban a tudást, mialatt mi a fejünket valami jobbra használjuk. Az ismeretek számára a könyv biztosabb otthont nyújt. Az én fejemben bármilyen könyvszagú ismeretnek a felezési ideje néhány hét. Így hát az ismereteket biztos megörzésre a könyveknek, könyvtáraknak hagyom, és inkább horgászni megyek, néha halra, néha új ismeretekre.

Ifjúságról: Ifjúságunk a jobb jövő egyetlen reménye. Bizonyos dolgokra csak fiatalon fogékony az agy, később „,befagy”, többé nem formálható. Az embernél a befagyás, úgy látszik, a negyedik évtized során megy végbe. A gerontokráciáról (az öregekből álló politikai vezető réteg uralma- a szerző) vallott ezen nézete is hozzájárult ahhoz, hogy 'Az örült majom' c. könyve az öreg kommunista vezetők korában nem, csak 1989-ben jelenhetett meg Magyarországon. Ebben foglalta össze pesszimista nézeteit a tudományról, az ember fennmaradásáról

Sportról: A sport nemcsak testnevelés, hanem a léleknek is az egyik legerőteljesebb nevelőeszköze. A sport fogalma nem tévesztendő össze a puszta testi ügyességgel, a rekord-hajhászással, a nyereségvadászással és a legutóbbiakkal együtt járó primadonnáskodásokkal. Ez utóbbiaknak nemcsak, hogy a sporthoz semmi közük, de a sportnak egyenesen ellenségei.

Kiemelkedö képességüekről: Ha feleannyi pénzt és gondoskodást fordítanánk a kiemelkedő képességü gyerekekre, mint amennyit a fejlődésben visszamaradottakra fordítunk, a jó vezetők nem lennének olyan ritkák.

Tudományról: A tudomány elsődleges célja, hogy igazságra, méghozzá új igazságra találjon. Ez a kutatás annál eredményesebb, minél inkább arra irányul, hogy az igazságot önmagáért keresse, függetlenül esetleges gyakorlati hasznától, és felhasználhatóságától. A tudomány az emberi kíváncsiság eredménye. Fejlődését nem lehet megállítani csak az emberi természet megváltoztatásával. A tudomány megváltoztatta az emberi élet arculatát. Ha mindent kidobnánk, amit a tudomány alkotott, meghalnánk.

Tudományos módszerről: lényege, hogy a problémákat, mint problémákat kezeli, így keresi a legjobb megoldást, elöítéletek és sovinizmus nélkül. Nem azt kérdezzük, hogy kinek van igaza, hanem azt, hogy mi az igazság.

Kutatásról: A kutatás igazi önzöket igényel, akik saját örömüket és megelégedettségüket keresik, de azt a természet rejtélyeinek megoldásában találják meg.

Kutatókról: A tudományos kutatót az emberi tudás térképén levő fehér foltok nyügözik le, és ha szükséges, kész életét áldozni, hogy a fehér foltokat megszüntesse. Egy alkotó tudósnak, vagy müvésznek abban kell elégedettséget találnia, hogy alkotott valamit - valamit, ami nem volt ott azelőtt, bármilyen kicsi is legyen.

Tudósok felelösségéről: A tudósok hozták létre a rombolás eröit. Bünösségüket mérsékli az a tény, hogy időben felhívták a figyelmet arra, hogy ezeket rossz célra is lehet használni; nem hibáztathatók, amiért szavaik süket fülekre találtak. Föl kell emelni szavunkat amerikaiként, tudósként a tudomány eredményeivel való gyalázatos visszaélésekkel szemben, ne használják gyilkolásra és pusztításra. [22/122, 113]

http://www.kaleidoscopehistory.hu

Varga János mérnöktanár 
Kreativitásról: A kreativitáshoz tartozik az örök kíváncsiság, az a képesség, hogy gyermeki módon csodálkozzam a természeten, és felismerjek egy csodát, még akkor is, ha mindennap látom. A kreativitás másik fontos ismérve: felvetni egy jó problémát, kérdezni egy jó kérdést, már a munka felét jelenti.

Felfedezésről: Látni, amit mindenki lát, és gondolni, amit még senki sem gondolt. Minél alapvetőbb egy felfedezés, annál távolabb esik a gyakorlati felhasználástól, annál kevésbé függ össze a mindennapi problémákkal. Mégis ezek a nagy alapvető felfedezések viszik elöre az emberiséget. Egy modern felfedezés azért felfedezés, mert ellentétben áll az összes ismert tudással. Ha nem áll ellentétben, akkor csak egy kis adalék. Ahhoz, hogy az ember valami egész újat meglásson, ahhoz egész másképp kell gondolkodni. És ha az ember másképp gondolkodik, azt mondják, hogy bolond.

Nőkröl: A nőknek több a józan esze, mint a férfiaknak.

Szexrôl: Szememben fiatalságunk egyik legnagyobb érdeme - hatalmas emberi bátorságának jele - az, hogy az egyik legerősebb emberi érzésnek, a szexuális vonzódásnak képes volt visszaadni a tisztaságát és méltóságát. - fogalmazott 1970-ben a Tudós felelössége címü iratában.

Erkölcsről: Régi erkölcseink alapja a terhességtől és nemi betegségektől való félelem volt, mivel az erkölcs nem más, mint a társadalom létét biztosító elöírás. Olyan szabályok gyüjteménye, amely lehetővé teszi az együttélést, és a körülményektöl függ. [5, 67. o.]

Bírói döntésröl: Minden bírónak börtönben kellene töltenie valamennyi időt, hogy felfogja, mit tesz azokkal, akiket börtönbe juttat. [5, 31. o.]

Hadseregről: A hadseregek nem a béke, hanem a háború szervezetei. Minden hadsereg fenyegetés a béke ellen; minél nagyobb a hadsereg, annál nagyobb a fenyegetés. Le kell ráznunk és el kell üznünk minden hadsereget, és minden héját, amely a seregeket támogatja. El kell kergetnünk a pusztító szerkezetek megszállottait. A hadsereg az emberiség átka, fenyegeti a békét, sőt puszta létünket is. Az emberi értelem és müveltség szégyenfoltja. A hadseregek értelemszerüen a szervezett öldöklés eszközei.

Háborúról: Nem igaz, hogy azért voltak mindig is háborúk, mert az ember vérszomjas. A háborúk mindig azért törtek ki, mert mindenkor voltak egyének vagy kis embercsoportok, melyek készek voltak mások életét feláldozni saját profitjuk vagy törekvéseik érdekében. Valamennyien egy kis bolygó lakói vagyunk, és merő képtelenség az állandó háborúskodás.

Ellenségröl: Legegyszerübben és legolcsóbban úgy szabadulhatunk meg egy ellenségtől, ha megbarátkozunk vele. (Szilárd Leónak is hasonló véleménye volt erről, ellentétben pl. Neumann Jánossal, aki még a SZU elleni elő csapástól sem riadt volna vissza abban a kritikus időszakban (1945-49), amikor annak még nem volt atombombája.)

Békéröl: A békéhez nem bombák kellenek, hanem jóakarat és emberi együttérzés. Akkor lesz béke, ha nemzeti büszkeség helyett visszatetszéssel szemléljük a gyilkolás és pusztítás eszközeit. Talán az emberi értelem megtalálja azt az utat a békéhez, amely nem halott gyermekek testén vezet keresztül. (Ide kívánkozik BOLYAI JÁNOS gyönyörü, hasonlóan szép gondolata: ,az egész emberi nem általános boldogítása fekszik nekem szívemen. Mi fölséges, édes érzés lesz, ha minden választékok leomolván, az ember az embert embernek nézi.")

Hatalomról: A politikus a következő választásra gondol; az államférfi a következő nemzedékre. Az emberek a legjobb politikusokra szavaznak, aztán csodálkoznak, hogy rossz államférfiakat kaptak.

Atomfegyverről: Ha atomfegyverrel rendelkező országok bármelyikében szélsőséges erők ragadják kézbe a vezetést, könnyen szakadékba taszíthatnak valamennyiünket. Az ember történelme során először talált rá módot, hogy egy atomháborúval közvetlenül károsítsa a DNS-t. Egy atomháborúnak is lehetnek túlélői, de ezeknek a túlélőknek soha többé nem lehetnek egészséges utódaik. (Professzortársa Kemény János

http://www.kaleidoscopehistory.hu

Varga János mérnöktanár 
szerint: „A világ legsúlyosabb gondjainak gyökere viszont a túlnépesedés. Ez veszedelmesebb robbanással fenyeget, mint akármilyen atombomba. De hiba volna ezért az orvostudományt tenni felelőssé.")

Vallásról: Volt egy tanárom, aki nagy hatást tett rám, nagyon intellektuális volt, ő keltette fel igazi érdeklődésemet. Hát ez a tanár ateista volt. A vallások mindig a hatalom oldalán állnak.

Politikai pártokról: Politikai pártjaink nem egyebek, mint személyes ambíciók eszközei. A politikus a következő választásra gondol, az államférfi a következő nemzedékre. Parva sapiencia regitur mundus. (Szegényes értelem kormányozza a világot.)

Túlnépesedésről: Vagy a túlnépesedést kell megakadályoznunk, vagy egy jobb és nagyobb bolygóra kell költöznünk.

Agyról: Az ember agyát nem azért alakította ki a természet, hogy az igazságot keresse, hanem azért, hogy élelem, biztonság és hasonló dolgok után kutasson, hogy felismerje az előnyös helyzeteket, hogy nap, mint nap segítse az embert az életben maradásban. Az agy a túlélés szerve.

Világról: Az ember történelme során először képes valóban élvezni az életet, elöször nem kell rettegnie a hidegtől, éhségtől és betegségektől. Most először tudja kielégíteni összes alapvető igényét. De történelme folyamán ugyancsak most először képes arra is, hogy egyetlen csapással elpusztítsa önmagát, vagy arra, hogy a szennyeződéssel és a túlnépesedéssel lakhatatlanná tegye ezt a szükülő, kedves földtekét.

Boldogságról: Gazdag az, akinek több a pénze, mint a vágya, és az a szegény, akinek a vágya több mint a pénze... A boldogság titka nem az, hogy még többet szerezzünk, hanem az, hogy örüljünk annak, amink van, és hogy kitöltsük életünk üres kereteit ahelyett, hogy azokat tovább tágítanánk.

Vitaminról: A vitamin olyan anyag, ami akkor okoz betegséget, ha nem esszük meg.

C-vitaminról: A C-vitamin világszerte hiányzik az emberi táplálkozásból. Az orvostudomány feladata, hogy megkeresse azokat a táplálékokat, amelyek pótolják ezt a hiányt, és hogy megtanítsa az embereket, hogy ezeket a táplálékokat fogyasszák.

Egészséges táplálkozásról: Ahhoz, hogy egészséges, kiegyensúlyozott legyen táplálkozásunk, nem szükségszerüen kell mesterségesen elöállított vitaminokat adagolnunk magunknak, hanem ... elegendö vitamint tartalmazó ételt kell ennünk.

\section{Munkásságával, életével kapcsolatos dokumentumok lelőhelyei}

A Szegedi Tudományegyetem (SZTE) Klebelsberg Könyvtárának Szent-Györgyi Albert gyüjteménye a vele kapcsolatos dokumentumok gazdag tárháza. A kar Dékáni Hivatalában a város, az egyetem és a kar állandó kiállítóhelyként Szent-Györgyi Albert Emlékszobát létesített a Nobel-díj odaítélésének 70. évfordulója lakalmából. A Somogyi-könyvtár Vasváry-gyüjteménye ${ }^{17}$ is tartalmaz vele kapcsolatos dokumentumokat. Szent-Györgyi Nógrád megyében, a Balassagyarmati járásban lévő Terény (szlovákul Terany) községhez tartozó, Buják melletti Kiskérpusztán gyerekeskedett. A Kruj Andor magántulajdonában lévő uradalmi magtárépület falán a tudós egyik gondolatát tartalmazó emléktábla is található. 
Kaleidoscope

\section{Emléktábla feliratok}
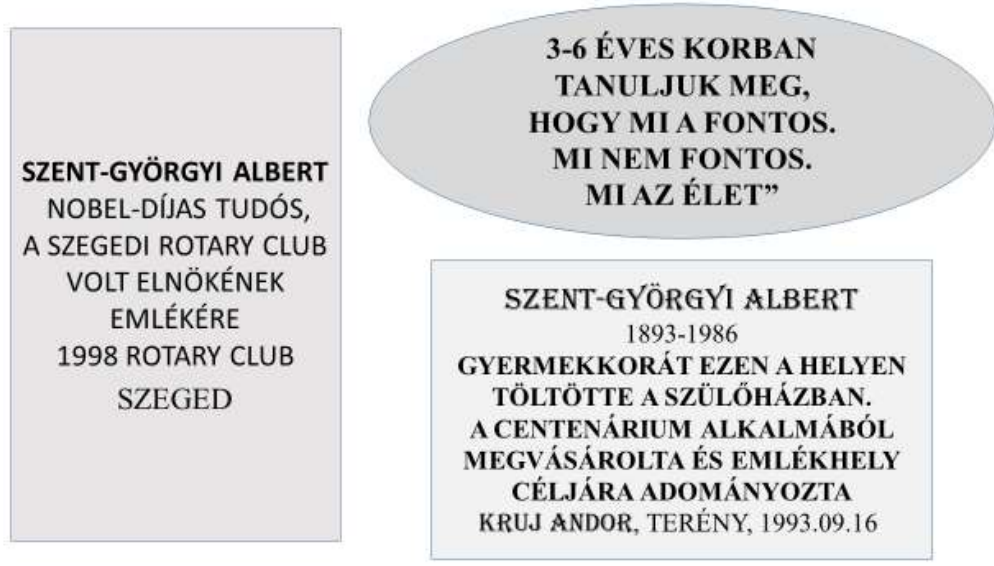

11. ábra emléktáblák és szövegük

Bujákon az Általános Iskola róla van elnevezve. A bujáki polgármester szívós kitartó munkával elérte, hogy a faluban életútját bemutató kiállítás nyílt. Negyedik felesége ide olyan anyagot küldött, amiből sokkal inkább megismerhető, hogy mint ember, mint tudós honnan indult el és hova érkezett. A Marcia Houston által adományozott Szent-Györgyi dokumentumok egy részét jelenleg az Eszterházy KÖZÖSSÉGI TÉR-ben őrzik. A hagyaték gondozója: Patkós István alpolgármester (volt polgármester), történelem- és irodalom tanár.

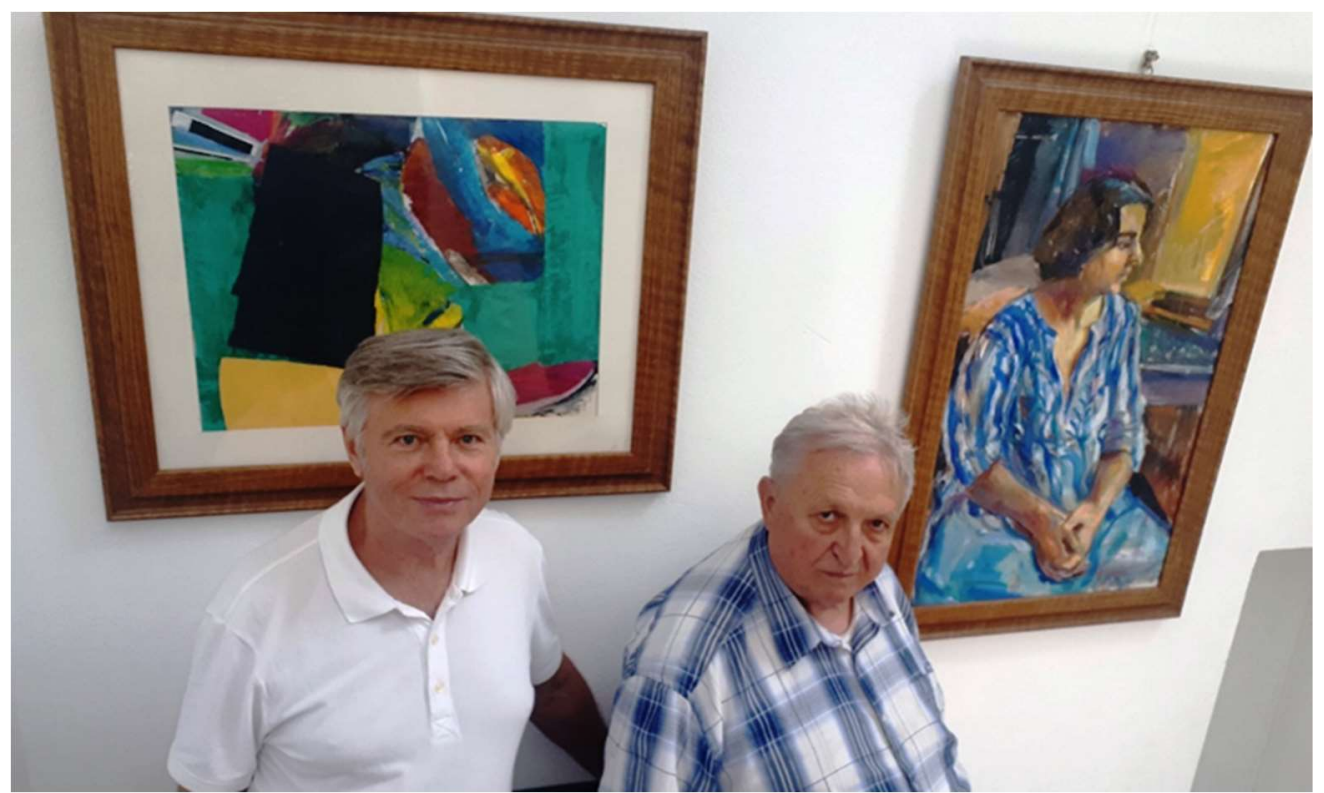

12. ábra Varga János szerző és Patkós István alpolgármester, hagyatékgondozó;

Itt örzik Szent-Györgyi Albert 1952. július 24-ig érvényes svéd útlevelét, amellyel Amerikába ment.

http://www.kaleidoscopehistory.hu

Varga János mérnöktanár 
Kaleidoscope

\section{Epilógus}

Összesen kétszer látogatott haza. Először $1973^{18}$ októberében, másodszor 1976-ban azzal a küldöttséggel, amely visszaszolgáltatta Magyarországnak a koronát. (A küldöttségnek tagja volt szegedi barátja, amerikai emigráns társa, a világhírủ fizikus, Bay Zoltán is.) Magyarságát mindig vállalta: „Én magyar ember vagyok, és e hazához tartozónak érzem magam. [...] Én a legbékésebb ember vagyok, mégis szeretném, hogyha Magyarország az egész világot meghódítaná. Az ország határait nem lehet bővíteni politikailag anélkül, hogy az ember másokat el ne tiporna, vagy meg ne bántana. A szellemi életben mindenki olyan nagy lehet, olyan nagyra fejlödhet, amennyit az esze elbír. Én ebben az értelemben kívánom, hogy Magyarország tartozzék a legnagyobb országok közé.”

1986. október 22-én 11 óra 30 perckor, a Bostonhoz közeli Woods Hole-ban az Egyesült Államok polgáraként halt meg, 93 éves korában, leukémia szerü betegségben és magas vérnyomásban. Ez utóbbi veseelégtelenséghez vezetett, ez volt halálának közvetlen oka. Különleges kívánsága halála esetére az volt, hogy második felesége, Márta mellé temessék el Woods Hole-ban, abba a sírhelybe, amit ő már korábban megvásárolt. Azóta ott pihen.

Imádta az életet, de a munka volt a legnagyobb öröme. Mivel hajlamos volt a hörghurutra (bronchitisre), rendszerint télen utaztak el délre, Arizonába, a Karib-tengerhez, vagy Floridába. De még oda is magunkkal vitték a könyveket, az írógépet és még a bérelt vitorlásukon is diktálta az anyagot. Soha nem tudta, nem akarta abbahagyni a munkát. Az utolsó egy hónapot leszámítva, amikor már teljes ápolásra szorult, a rák elleni kutatásokkal foglalkozott. Tudatában volt annak, hogy jelentős életmüvet hagy maga után, de úgy tünik, hogy a tudomány képviselői, a tudománytörténet ezt igazán a mai napig nem ismerte fel. „Ha végigtekintek életmüvemen, azt kell gondolnom, hogy befektetésük (mármint az adófizetöké- a szerző) nem volt hiábavaló. [5, 84. o.]"

Magyar maradt haláláig. Hazatelepülésre nem gondolt, de szívesen jött látogatóba. Volt, amikor csak inkognitóban járt itthon negyedik feleségével, senki sem tudta, hogy itt járt, csak az Akadémia adott tiszteletére egy vacsorát. Amerikában is angolul beszélt, de magyar beszédén ezt nem lehetett észrevenni. Unokatestvérével, Andrással, aki szinte minden héten meglátogatta, magyarul beszéltek. Amerikában élő magyar barátaival, Neumann Jánossal, Bay Zoltánnal, és másokkal is természetesen mindig magyarul beszélt, ugyanígy azokkal is, akik a szülöhazájából felkeresték. 1986. december 15-én vette föl nevét a szegedi orvosi egyetem. A nagyszabású névadó ünnepség alkalmából szobrát volt intézetének bejárata előtt, a szegedi Dóm téri panteonban avatták föl 1986. december 11-én. Bíró Lajos mátészalkai szobrászmüvész által bronzból készített egész alakos, életnagyságú (közel 190 centiméter magas) bronzszobrát születésének 120. évfordulója alkalmából 2013-ban avatták fel a Rektori Hivatal elött. (A lépcsőn lefelé jövet, pipáját jobb kezében tartva ábrázolta a müvész.) Mögötte az egyetem épületének falán egy bronztáblán olvasható a tudós neve, születési és halálozási éve, valamint a „Nobel-díjas” felirat.

Nemrégiben a Goodwill Pharma Kft. vezetői bejelentették: kezdeményezték, hogy Szent-Györgyi Albert születésnapja, szeptember 16. legyen a $C$-vitamin világnapja, és alapítványuk létrehozta a SzentGyörgyi Albert Orvosi Díjat, amelyet egy-egy évben 7 személynek ítélnek oda. A díjra olyan szakembereket lehet jelölni, akik cselekedetükkel megmentették betegük életét, vagy akár a mindennapi orvosi munkájuk során olyan elhivatottsággal praktizálnak, melyben rendkívüli odaadással, tudományos igényességgel és humanitárius szemlélettel segítenek a hozzájuk fordulókon. Első alkalommal 2018. április 26-án a Magyar Tudományos Akadémián adták át a díjat.

http://www.kaleidoscopehistory.hu

Varga János mérnöktanár 
Életéről részletesebben hallhatunk a www.picaso.hu oldalon található, e sorok írójával készült rádió interjúban.

\section{Irodalom}

1. SZENT-GYÖRGYI Albert: Egy biológus gondolatai, Gondolat, 1970

2. SZENT-GYÖRGYI Albert: Az élet jellege. (Gyorsuló idő), Magvető, 1973

3. SZENT-GYÖRGYI Albert: Az anyag élő állapota. (Gyorsuló idő), Magvető, 1983

4. SZENT-GYÖRGYI Albert: Válogatott tanulmányok, Gondolat, 1983,

5. SZENT-GYÖRGYI Albert: Az örült majom. (Gyorsuló idő), Magvető kiadó, 1989, 108 o.

6. NAGY Ferenc: Szent-Györgyi Albert és a magyar Nobel-dijasok, Müszaki és Természettudományi Egyesületek Szövetségi Kamarája (Budapest), 1993, 54 oldal

7. BAY Zoltán, Dénes Gábor, Nagy Ferenc, Wisinger István: Szent-Györgyi Albert, Dokumentumok, Riportok, (Sorozatcím: Egyéniség és alkotás) Akadémiai Kiadó (Budapest), 1989.

8. SzABÓ Tibor, Zallár Andor: Szent-Györgyi Albert Szegeden és a Szent-Györgyi Gyüjtemény (Tanulmányok

Csongrád megye történetéből 15.), Szeged, 1989, 112 o.

9. MARTON János-PAP Kornélia: Kihívások, küzdelmek, kalandok a tudományban és a társadalomban, Szent-Györgyi Albert Magyarországon, Gondolat Kiadói Kör Kft., 2017, 394 o.

10. CzEIZEL Endre: Szent-Györgyi Albert, Müszaki Kiadó, 55 o. (Sorozatcím: Magyar feltalálók, találmányok)

11. CZEIZEL Endre: Szent-Györgyi Albert genealógiája, VALÓSÁG, 1996/2, 69-79 o.

12. CZEIZEL Endre: Szent-Györgyi Albert, Egy magyar tudós útja a Nobel-díjig, In.: RUBICON, 2014/12:25-41. o.

13. JUHÁsz Gyula: A Szent-Györgyi-misszió hatása. Közreadja: Romsics Ignác, In.: RUBICON, 2014/12:16-19.o.

14. KAPRONCZAY Károly: Szent-Györgyi Albert ösei, In.: RUBICON, 2014/12: 20-24. o.

15.1937 évi kémiai Nobel-díj: https://www.nobelprize.org/nobel prizes/chemistry/laureates/1937/

16. Norman Haworth: https://www.nobelprize.org/nobel_prizes/chemistry/laureates/1937/haworthfacts.html

17. Paul KARRER: https://www.nobelprize.org/nobel_prizes/chemistry/laureates/1937/karrer-facts.html

18. Hans KREBS: https://www.nobelprize.org/nobel_prizes/medicine/laureates/1953/krebs-facts.html

19. Fritz LIPMANN: https://www.nobelprize.org/nobel_prizes/medicine/laureates/1953/lipmannfacts.html

Fotók: https://profiles.nlm.nih.gov/ps/retrieve/Narrative/WG/p-visuals/true

20. WISINGER István: A Nobel-dijas kém, 2017, Athenaeum Kiadó, 448 o.

21. VARGA János: 90 évvel ezelött született KEMÉNY JÁNOS, az informatika úttöröje, VALÓSÁG, 2016/8, 92-96

22. HANNUS István:Szent-Györgyi Albert a The New York Times hasábjain 1933 és 1986 között, Szeged 2010,128 o.

23. JÓZSEF Attila: Tanulmányok, cikkek, levelek. (Magyar remekírók.) Budapest: Szépirodalmi Könyvkiadó, 1977. 478-482. p. 
24. Albert SZENT-GYÖRGYI: Oxidation, Energy Transfer, and Vitamins, Nobel Lecture, December 11, 1937

https://www.nobelprize.org/nobel_prizes/medicine/laureates/1937/szent-gyorgyi-lecture.pdf

25. Fotók: Feleségek fotói: Demény Kornélia, Borbíró Márta, és Marcia Houston portéit a Szegedi Tudományegyetem Klebelsberg Könyvtár Szent-Györgyi Albert gyüjteménye digitalizálta és bocsátotta rendelkezésemre. Egyéb fotók: Liebmann Béla felvételei.

26. LÁszLÓ Ágnes: Az asszony, aki az emlékeivel él, Exkluzív interjú Szent-Györgyi Albert özvegyével (Marcia Huston), https://librarius.hu/2017/09/26/szent-gyorgyi-albert-felesege-egyszemelyben-voltamaz-asszonya-titkarnoje-baratja-es-soforje/

27. Moss, Ralph W.: Szent-Györgyi Albert, Budapest, Typotex, 2004, 341 o. + fotó melléklet

\section{JEGYZETEK}

\footnotetext{
${ }^{1}$ Ez az oka annak, hogy nevét még a szakmabeliek is gyakran 'hibásan' Szentgyörgyi-nek írják, és ismeretterjesztő cikkek tucatjaiban másolódik tovább ez az eredetileg helyes, de ma már hivatalosan hibás névírás.
}

${ }^{2}$ Mivel az anyagnak feltételezései szerint hat szénatomja volt - a tudóstársai számára elfogadhatóbb hexuronsavnak nevezte el (a hex görögül hatot jelent).

${ }^{3}$ A fumársav előfordul a sejtekben a citromsavciklus folyamatában, amely cukrokból termel energiát ATP formájában. Az emberi bőr napfény hatására fumársavat termel. A fumársavat 1946 óta használják élelmiszer savasság-beállítóként, mivel nem mérgező. Italokban és sütőporokban használják, amelyeknek tisztasági követelményeknek kell megfelelniük. A fumársavat poliészter gyanták és cukoralkoholok gyártásánál valamint színezékek pácolásához is felhasználják.

${ }^{4}$ Az aszkorbinsav elkülönítésére talán soha nem nyílik lehetőség, ha Szent-Györgyi Albert professzor felesége egy nap nem füszerpaprikát szolgált fel vacsorára Mivel nem szerette volna megbántani feleségét azzal, hogy nem értékeli konyhai teljesítményét, a professzor a tányérját a laboratóriumba vitte. Ott végső reményként a paprika analizálásába kezdett, és végül kinyerte belöle az aszkorbinsavat. Egy nap alatt fél font $(\approx 250 \mathrm{~g})$ tömegben jutott a becses anyaghoz, 10 -szer annyihoz, mint amennyit a Chicago melletti marhavágóhidakról tonnaszám kapott mellékvesekéregből 1 év alatt összesen ki tudott vonni! . (Sokan, hibásan úgy tudják, hogy Szent-Györgyi a paradicsompaprikából állította elő a C-vitamint!)

${ }^{5}$ Az intézetet ALFRED A. STRELSIN iparmágnás, emberbarát és művészetpártó alapította 1947-ben. Strelsin egy szegény belga bevándorló vállalkozó szellemü fiaként újságíróból lett tönkrement cégek, üzleti vállalkozások újjáélesztésének mestere, aki 78 éves korában, 1976 augusztusában halt meg New Yorkban.

${ }^{6}$ Annak ellenére, hogy ez a magyarázat igazolta a fény kvantumtermészetét, a kvantummechanikával kapcsolatban Einsteinnek egész életében fenntartásai voltak. Elsősorban a mikrorészecskék valószínüségi leírása ellen tiltakozott, mint mondta: Isten nem szerencsejátékos.

${ }^{7}$ Nem Szent-Györgyi volt az egyetem egyetlen magyar származású professzora. Kemény János 1953-70-ig matematika professzor,1955-67-ig a Matematikai Tanszék vezetője, 1970-ben a főiskola rektora lett, ezt a tisztet 1981-ig töltötte be munkásságával, eredményeivel téve világhíressé a kis vidéki föiskolát. Rektori müködését történelmi fordulatnak ítélik Új Angliában. (Részletesebben lásd az Irodalom 21. tételét.)

${ }^{8}$ Alex Fanelli, Kemény rektori titkárságának vezetője 1984. április 3. és szeptember 4. között, 9 alkalommal egy 18 órás interjúsorozatot készített Kemény Jánossal, amely írásban hozzáférhető a Dartmouth Egyetem honlapján, illetve a JOHN KEMENY SPEAKING, Selected Addresses, Talks and Interviews by JOHN G. KEMENY from the years of his Presidency of http://www.kaleidoscopehistory.hu

Varga János mérnöktanár 
Dartmouth College, 1970-1981, Edited by A. Alexander Fanelli, DARTMOUTH COLLEGE Hanover, New Hampshire, 1999, 319 o. könyvben. ( KemenyInterview.pdf (3.2 MB)

http://www.dartmouth.edu/ library/rauner/archives/oral_history/oh_interviews_pdf/KemenyInterview.pdf)

${ }^{9}$ Nekünk, magyaroknak büszkéknek kell lennünk arra, hogy a világon mindenkit megelözve egy Szegeden tanárnak készülö, de a Tiszta szívvel címü, 1925 márciusában írt verse miatt a Szegedi Tudományegyetemről kirúgott magyar költő, JózSEF ATTILA, Szent-Györgyit is jóval megelőzve szintén sokat gondolkodott az elektronon. 1926 januárjában a makói gimnázium tanárhoz és pártfogójához, Galamb Ödönhöz, Bécsből írt levelében már leírta az elektron „ikertestvérét” és pozitív elektronnak nevezte (később pontosan ebből a szóösszetételből született meg a pozitron szó), sőt felvetette a párhuzamos univerzum létezésének koncepcióját is. Levelében szó szerint ezt írta: „... a transznegatívumról szóló elméletem szerint, amire eddig senki sem gondolt ... jelen van egy másik univerzum is. T.I. a mi univerzumunk a pozitiv és a negatív elektrónok rendszere, és a másik jelenlevő univerzum pedig azoké, melyekhez képest a jelen ismert negatívok-pozitívak; .[23]" Megdöbbentő, hogy a világ tudományos közvéleménye elött a mai napig nem ismert ez a két, dokumentummal is bizonyítható magyar tudománytörténeti eredmény. József Attila tehát a világon mindenkit megelözött ezen antirészecske kitalálásában. A pozitront, mint az elektron antirészecskéjét a fizikusok közül először PAUL DIRAC jósolta meg 1928-ban -tehát József Attila után 2 évvel!- elméleti megfontolásokból. ROBERT J. OPPENHEIMER elméleti fizikus, a fizikusok közül elsőként jósolta meg helyesen a pozitron tulajdonságait. CARL DAVID ANDERSON pedig csak 1932-ben fedezte fel ténylegesen a kozmikus sugárzásban, melyet mágneses térben lévő ködkamrával vizsgált. Ezért a felfedezéséért 1936-ban fizikai Nobel-dijat kapott. Ha a világ tudományos közvéleménye tudott volna József Attila ezen hipotetikus eredményéről, és esetleg 1/3 részben megosztva részesült volna az 1936-os fizikai Nobel-dijból, akkor az egyrészt szenzáció lett volna, mert költő még sosem kapott fizikai Nobel-díjat, másrészt pedig nagy valószínüséggel olyan lelki hatást váltott volna ki nála, hogy szinte biztosan nem lesz öngyilkos a következő évben.

${ }^{10}$ Fodor B. Gábor (1915-2000) a szegedi egyetemen 1937-ben szerzett vegyészdiplomát Bruckner Győző és Szent-Györgyi Albert tanítványaként. 1950 és 1956 között a szerves kémia tanszék vezetője. 1964-ben külföldre távozott, 1969-től a West Virginia Egyetem professzoraként újra együtt müködött Szent-Györgyivel. [22, 125.o.]

${ }^{11}$ Kezdetben támogatta LYNDON JOHNSON elnököt is, de néhány hónap után csalódott benne, mivel az elnök ígéretével ellentétben nem törekedett a vietnami háború befejezésére. 1966-ban 300 társával Szent-Györgyi aláírt egy kiáltványt, amelyben megtagadták az adófizetést az amerikai kormány vietnami és dominikai beavatkozása miatt.

12 Íme, a széleskörű tudományos tevékenységének nemzetközi elismerése.

${ }^{13}$ Pauling a háború után békeharcos lett. 1946-ban tagja lett az Albert Einstein és Szilárd Leó vezette Emergency Committee of Atomic Scientists (Atomtudósok Vészbizottága) nevü csoportnak, amely céljául és feladatául tüzte ki a nyilvánosság felvilágosítását az atomfegyverek veszélyeiről. Pauling nézeteit a nukleáris fegyverek kipróbálásával járó sugárzási veszélyekről a No More War! (Soha többé háborút!) címü könyvében (1958) fejtette ki.

${ }^{14}$ Azon a napon, amikor életbe lépett az atomcsend egyezmény, a Nobel-díj-bizottság Paulingot a Nobel békedíjjal tüntette ki. A díj adományozása politikai viharokat kavart, a „kriptokommunistának” tartott Pauling megjutalmazásakor az amerikai kormány tiltakozott. (A kriptokommunista olyan titkos kommunista, aki a Kommunista Párt megbízásából beépül egy másik pártba, önmaga kommunista nézeteit elrejtve és belülről próbálja azt a pártot szétverni, hogy a kommunista hatalomátvételt ezzel is elömozdítsa.)

${ }^{15}$ Bolyai János esetén ez a kívánalom teljesült, hiszen valóban különb lett édesapjától, és mint 1823. nov. 3-án Temesvárról apjának írt levelében olvasható: a semmiből egy újj más világot teremtettem. Megoldotta a matematika 2000 éves, megoldhatatlannak hitt problémáját, és kidolgozta az első nemeuklideszi geometriát, vagy, ahogy világhírü munkájának hosszabb címében olvasható: Appendix. A tér abszolút igaz tudománya a XI. Euklidész-féle axióma (a priori soha el nem dönthetö) helyes, vagy téves voltától független tárgyalásban; annak téves volta esetére, a kör geometriai négyszögesitésével.

${ }^{16}$ Székesfehérváron 2015-ben állítottak neki életnagyságú szobrot a Megyei Könyvtár bejárata előtt, a Bartók téren. Szobra volt fönökére - Klebelsberg Kuno vallás- és közoktatásügyi miniszterre- tekint, akinek szintén 2015-ben állítottak szobrot a híres Ciszterci Gimnázium bejárata előtt, a lépcsőlejárón. (A két szobor 50 m-re van egymástól.) Ebbe a gimnáziumba járt a később világhírủvé vált tudós, Einstein munkatársa, matematikai szekundánsa, LÁNCZOS KORNÉL is, de róla még egy megemlékező sor sincs a gimnázium vitrinjeiben, pedig 1926-ban a Zeitschrift für Physik által közölt, a kvantummechanikai problémák mezőszemléleten alapuló, integrálegyenletelhttfellhaszwákádáralogdapohơttortahulmányával egy hónappal megelőzte Erwin 
Schrödinger osztrák fizikus differenciálegyenletre alapozott hullámmechanikáját, amiért az fizikai Nobel-díjat kapott. (Egy megosztott Nobel-díj ez esetben is igazságosabb lett volna.) Klebelsberg Kunónak a gimnázium épületében - ahova 8 évig jártis van mellszobra, sőt 2014-ben a II. Rákóczi Ferenc Általános Iskolában is állítottak neki egy mellszobrot. A Zichy-ligetben lévővel együtt tehát Klebelsbergnek Székesfehérváron négy szobra is van. Csak reménykedni lehet abban, hogy Székesfehérvár egyszer majd legnagyobb tudósának is emléket állít a politikus szobrok után.

${ }^{17}$ Vasváry Ödön Szegeden született, mint alsóvárosi patrícius család gyermeke. Református lelkész lett, Szabolcs megyében, Gégényben kezdte pályafutását, ahonnan 1914-ben Pittsburgbe került. Mivel nagyon érdekelte az amerikai magyarok sorsa, Amerikában az amerikai magyarság történetének kutatója lett. Értékes anyagokat, könyveket, folyóiratcikkeket, kéziratokat gyüjtött amerikai magyar irodalmárokról, természettudósokról, zenészekröl, festőkről, stb. Felfedezéseit gyakran közreadta amerikai magyar nyelvü lapokban (Új Magyar Út, Szabadság, Amerikai Magyar Népszava, Amerikai Magyar Világ, stb.). Az Amerikai Magyar Református Egyesület lapjaiban (kivált a Testvériség c. lapban) gyakran publikált, az Amerika Hangja címủ rádióadásnak is készített cikkeket. 1972. május 16-án Washingtonban kelt adománylevelében szülővárosa könyvtárára, a Somogyi-könyvtárra hagyta nagyértékủ gyüjteményét.

${ }^{18}$ Véletlen egybeesés, hogy az év száma éppen megegyezik a Nobel-díj odaítélés éve (1937) számjegyeinek felcserélésével kapott számmal. Egy másik koincidencia születési dátuma (18모) utolsó két jegyének és életkorának (93 évet élt!) egybeesése. 